AN INVESTIGATION OF THE ECONOMIC IMPACT OF THE

OZARK DAIRY MANAGEMENT COMPONENT ON

LOW INCOME DAIRY FARMERS

\author{
A Thesis \\ Submitted to \\ the Faculty of the Graduate School \\ University of Missouri-Columbia
}

In Partial Fulfillment

of the Requirements for the Degree

Master of Science

by

Handy Williamson, Jr.

August 1971

Dr. Kenneth C. Schneeberger, Thesis Supervisor 
The undersigned, appointed by the Dean of the Graduate Faculty, have examined a thesis entitled

\section{AN INVESTIGATION OF THE ECONOMIC IMPACT OF THE OZARK DAIRY MANAGEMENT COMPONENT ON LOW INCOME DAIRY FARMERS}

presented by Handy Williamson, Jr.

a candidate for the degree of Master of Science

and hereby certify that in their opinion it is worthy of acceptance.

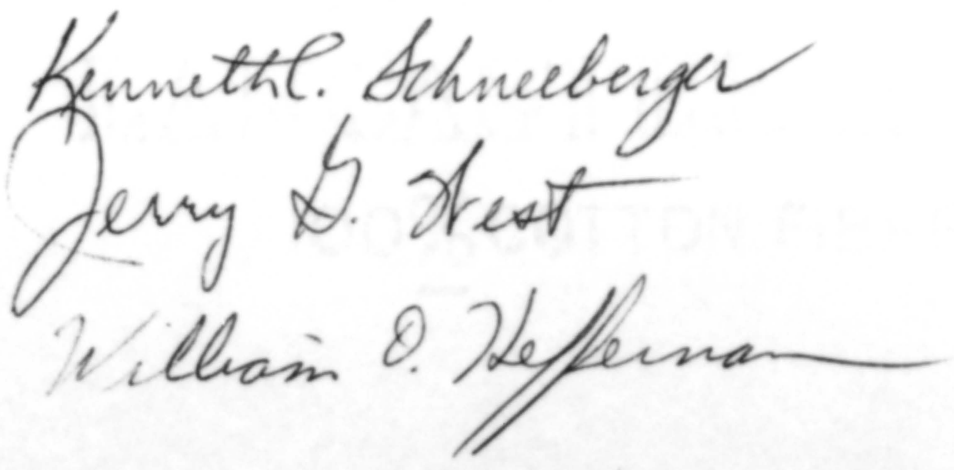




\section{ACK NOWLEDGMENT}

Without the immeasurable assistance of many individuals, this research endeavor could not have been consummated. Therefore, the writer wishes to extend wholehearted appreciation. Thanks goes especially to my advisor, Dr. Kenneth C. Schneeberger, who provided direction and encouragement throughout the course of this investigation. Sincere thanks are extended to Dr. Jerry G. West who read the manuscript and offered valuable suggestions. Drs. Al Lane and Rex Rickets of the University of Missouri Dairy Science Department, Dr. Don Voelker, Extension Dairyman, Iowa State University, Ames, Iowa; Dairy Management Component Participants, and others of the Department of Agricultural Economics, University of Missouri contributed immeasurably to this study.

Although data, assistance and encouragement was extended by many individuals and sources, the interpretations and conclusions are solely those of the author. 
The author is grateful to his wife Barbara Jean, for the many sacrifices endured and for special understanding and encouragement. Her constant support, patience, and assistance during felt difficulties enabled me to achieve my educational objective. 


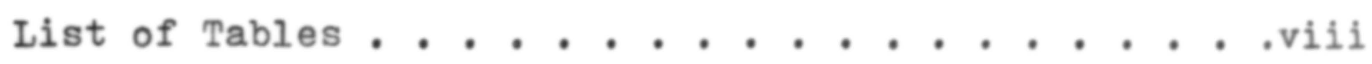
List of Figures. . . . . . . . . . . . . xi

CHAPTER

I. INTRODUCTION . . . . . . . . . . . . I 1

THE OZARK DAIRY MANAGEMENT CONPONENT . . . 2

Purpose and Objectives ........ 2

Projected Evaluation......... 3

The Component's Program of Work. . . . . 4

Clientele........... 4

Objectives.......... . . 4

Implementation steps; Personnel . . . 4

procedures ............ 5

Personnel Career Advancement . . . . ?

NATURE OF THE PROBLEM.......... ?

STATEMENT OF OBJECTIVES. ........ 9

SIGNIFICANCE OF THE STUDY. . . . . . . 9

METHODOLOGY. .............. 10

Population and Sample....... 10

Data, Sources and Collection ..... 12

ORGANIZATION OF THE THESIS ....... 13

II. REVIEW OF RELATED LITERATURE ....... 15

POVERTY, DELINEATION AND ALLBVIATION . . . 15 
CHAPTER

IMPACT ANALYSIS CASE STUDIES . . . . . 20

PEASIBILITY STUDIES. • . . . . . . . 26

Benefit Cost Analysis. . . . . . . 28

Formulation of B/C Ratio.. . . . 29

Risks. . . . . . . . . . 31

Depreciation . . . . . . . . 31

Interest Rate. . . . . . . . . 31

Internal Rate of Return. . . . . . 32

III. DEMOGRAPHIC AND SOCIO-ECONOMIC CONSIDERATIONS. 35

THE STUDY AREA PROFILE . . . . . . . 35

Agricultural profile . . . . . . 36

Population: Some Characteristics. . . . 41

Area Age Profile......... . 41

Status of Area Poverty ....... 43

SONE CHARACTERISTICS OF PROJECT

PARTICIPANTS ............. 44

Age. . . . . . . . . 46

Educational Levels ........ 46

Length of Component Participation. . . . 46

Size of operations ....... 48 
CHAPTER

IV. PERFORMANCE AND ATTITUDES OF SAMPLE GROUPS . . 50 INCONE OVER FEED COSTS . . . . . . . 51 Grouping By Years of Participation... . 53 HERD SIZE. . . . . . . . . . 56 Herd Size By Groups. . . . . . . . 57 Production: Volume and Value . . . . 62 Feed Costs . . . . . . . . . 67 INVESTMENT . . . . . . . . . 69 Investment Volume. . . . . . . . 71 Use of Investment. . . . . . . . 73 Credit Sources . . . . . . . . 73 Repayment Terms of Loans . . . . . 76 PARTICIPANT ATTITUDES REGARDING THE COMPONENT. . . . . . . . . 78 Change in Managerial Ability . . . 78 Attitudes Toward Dairy Aides . . . . 80 Participation in Educational Activities. . 82

V. INVESTMENT PEASIBILITY ANALYSIS. . . . . 84 IDENTIFICATION OF INVESTMENT SPENDING. •. . 84 INTERNAL RATE OF RETURN. . . . . . . 85 Schedule of Investment . . . . . . 86 Schedule of Net Benefits . . . . . 86 
Assumptions Regarding Net Benefits . . . 92

Case I Results . . . . . . . . . 94

Case II Results. . . . . . . . 95

Case III Results ......... . 95

Case IV Results. . . . . . . . 96

Implications of IRR Analysis . . . . . 96

VI. SUMMARY, CONCLUSIONS AND RECOMMENDATIONS . . 98 SUMMARY. . . . . . . . . . . . 98 Investment . . . . . . . . . 100 Use of Investment. . . . . . . . 100 Investment Feasibility . . . . . . . 101 Participant Perception of the Component. . 103 CONCLUSIONS. . . . . . . . . . . 104 RECOMMENDATIONS. . . . . . . . 105 BIBLIOGRAPHY . . . . . . . . 107 APPENDIX A ............................. APPENDIX B........................ 114 


\section{LIST OF TABLES}

TABLE

PAGE

I. Land Area; Proportions of Land in Farms;

Farm Sizes and Numbers; Incomes; and

Level of Living Indices by County In

the Area of Study. . . . . . . . . 38

II. Population and Population Profile For the

Six Counties Focused Upon by the Study . . . 42

III. Poverty Indicators by County As Indicated

in Community Profile Reports... . . . 45

IV. Educational Attainment of the Low Income

Dairy Farmers by Groups Based on Years

of Project Participation ... . . . . . 47

V. Income Over Feed Cost Per Herd and Per Cow

on an Annual Basis for Thirty Farmers; by

Year of Component Participation. . . . . 52

VI. Average and Median Income Over Feed Cost

Values Per Cow and Per Herd by Year and

by Groups Based on Length of Component

Participation. ........... 54

VII. Average, Median, and Range of Cow Number

Per Herd and Proportion in Milk by

Groups and by Year of Component

Participation. . . . . . . . 58

VIII. Volume of Production Daily and Annually by Herd and By Year of Component Operation. .

IX. Average Total Pounds of Milk Produced Daily and Annually by Herd Size Category and by Year of Component Participation .....

X. Average, Median, and Range Values of Peed Cost Per Cow Dally, and Per Hundred Pounds of Milk Produced by Size Category in Years One, Two, and Three of Component

Participation. 
XI. Per-Day Value of Production Per Cow As Recorded For the 30 Herds Included in the Sample, by Size Category and Year of Component Participation . . . . . . . 70

XII. Investment During the Period (1966-1970) by the Low Income Dairy Farmers by Length of Participation in the Component.

XIII. Proportions of Group Investment Used in Various Use-Categories . . . . . . . 74

XIV. Credit Sources and Proportion of Loans Secured From Each Source During 19661970 . . . . . . . . . . . 75

XV. Repayment Terms of Loans by Farmer Groups Based on Length of Participation and By Length of Repayment Periods . . . . . .

XVI. Participant Opinions Regarding Resultant Ability To Do A Good Job At Dairying . . . 79

XVII. Opinions Regarding Assistance Received from Dairy Aides with the Ozark Dairy Management Component ..........

XVIII. Attendance of Meetings and Farm Tours by the Low Income Dairy-Farmer Participants ............

XIX. Internal Rate of Return on Investment and Improved Management For A Representative Dairy Farm in The Ozark Dairy Program; Case I; No Improvement In Productivity

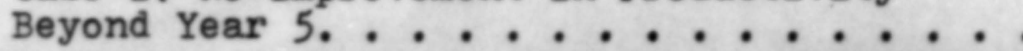

$X X$. Internal Rate of Return On Investment and Improved Management For A Representative Dairy Farm in The Ozark Dairy Project, Case II; Net Revenue Increased at 20 Percent Per Annum. 
TABLE

XXI. Internal Rate of Return on Investment and Improved Management For A Representative Dairy Farm in The Ozark Dairy Project; Case III: Net Revenue Increased At Decreasing Rate. . . . . . . . . . .

XXII. Internal Rate of Return On Investment and Improved Management For A Representative Dairy Farm in The Ozar'k Dairy Project; Case IV: Net Revenue Increased At A Constant Rate. 


\section{IIST OF PIGURES}

\section{FIGURE.}

I. Map of Study Area Showing the Location of the Six Counties Wherein the Low Income Dairy Farmers Resided. . . . . . . . . 37

II. Diagramatic Exposition of Herd Size Fluctuation over Three Years of Component Participation. ............ 60 


\section{CHAPTER I}

\section{INTRODUCTION}

To enhance the mobilization and coordination of community anti-poverty resources, the Economic Opportunity Act of 1964 provided for community action programs (C.A.P.). This type program was to be instrumental in improving and expanding services available to the poor at the community level. ${ }^{1}$ one stratagem was that of establishing community action projects adaptable to existent resource endowments and community frameworks. These projects were to provide for community motivation whereby community socio-economic standards could be raised.

One project receiving OEO support was the ozark

Dairy Management Component (ODMC) developed by the Ozark Area Community Action Corporation. The Ozark Dairy Management Component was an extension of the Webster County Dairy Management Component (WCDMC) launched April 1, 1966. Initially funded with $\$ 28,331.20$ the Webster County Dairy Management Component was to provide assistance to low income dairy farmers in Webster County, Missouri. After two years operation the WCDMC was extended to six counties

\section{${ }^{1}$ Levitan, Sar A.. The Great Society' s Poor Law--A} New Approach to Poverty. (The John Hopkins press, Baitimore, Maryland 1969, p. 3). 
and became the Ozark Dairy Management Component.

\section{THE OZARK DAIRY MANAGEMENT COMPONENT}

\section{Purpose and objectives}

The Ozark Dairy Management Component, initiated April, 1966, had set forth as a major purpose; the improvement of management practices among low income dairyfarmer participants. Accomplishment of the primary and secondary objectives was to have resulted in income levels at least equal to and greater than minimum designated poverty level. 2 Subobjectives as stated in the project proposal, were:

1. To raise income per cow at least $\$ 200$ over feed costs.

2. To insure enough cows to justify the dairy farmer's time, equipment and investment.

3. To insure enough acreage per cow to furnish a reserve supply of pasture, hay, and other roughage.

4. To assist in securing financing, where needed, whereby the dairy farmer could increase his income by a sufficient amount to pay off borrowed capital, interest, and increase net income.

2 The Proposers of the "Ozark Dairy Management Component." The Original Proposal submitted April, 1966, Ozark Area Community Action Cooperation. 
5. To assist in improving milk quality.

6. To improve and maintain herd health.

\section{Projected Evaluation}

The evaluation techniques were employed to (a)

assess increase in total income and income over feed cost from computer record data, and (b) assess the change in attitudes by noting new practices adopted, new services used, and meetings and tours attended. The evaluation was executed according to the following guidelines;

a) Evaluation was carried out each month

b) Each client was evaluated quarterly for ascertaining an increase in income, and readiness for graduation

c) An advisory group, made up of representatives elected by the group-to-be-served residing in each area, evaluated and advised program operations.

d) The advisory group elected a representative to the local board from Webster and in each county board depending on residence.

e) An advisory committee made up of elected representatives from the group-to-be-served, the ccunty EOA board, and the Extension Council supervised policy and procedures. 


\section{The Component's Program of Work}

Clientele: The component served approximately 120 low-income farmers in Christian, Dallas, Greene, Hickory, Polk, and Webster counties.

Objectives: To raise 120 low-income farmers from poverty, in the area served, by better use of their resources and scientific agriculture, to offer job placement and other alternatives of self-employment through related agencies to dairy aides and low-income farmers, and to improve quality of farm products with lower production and processing costs.

Implementation steps: Personnel...The program was implemented through the use of agricultural and feeder pig aides, and dairy aid counselors supervised by an Area Dairy Agent. The aides were hired in the area to-be-served from qualified people in the target group. Those aides deemed to have previously shown competence in the Webster Dairy Component were retained as Dairy Aide Counselors to help train new aides and also work with clientele in their respective areas.

New aides were given training by the director, extension personnel, and dairy industry representatives. Their field training was given by Dairy Aide Counselors. Such training and counseling were given regularly to all participating aides. The aides who were not high scheol 
graduates were encouraged to obtain their high school equivalency. The project's director kept informed through regular in-service training.

\section{Procedures:}

1) Identification of personnel was accomplished primarily by the aides in their own assigned areas. A questionnaire was used in identification of new clientele according to OEO poverty guidelines. Lists of patrons from milk companies were also used in locating new personnel.

2) Clientele were started on the herd testing programs (each having to pay $1 / 3$ of the costs). The computerized records were of assistance to dairy aides in advising on management practices. The aides offered such services as mastitis and disease control, equipment inspection, help in soil testing, and counselling in farm management, and off-farm employment opportunities. Management ideas were conveyed in a monthly newsletter.

3) Clientele were asked to state their aims and goals to help give direction to service given.

4) Within three to six months the client began taking his own samples and using the D.H.I.A. tester's services, at $2 / 3$ of the costs. The aides continued the provision of other services. 
5) The aides evaluated and kept records of changes in attitudes and practices each month. Each three months, the clients were evaluated for income. Had enough change in income and attitude been realized, the client was graduated from the program to the regular D.H.I.A. owner sampler program and paid full cost. The client was encouraged to use all the government and private services available to continue his economic growth.

6) Tours were held for clientele, to show methods and results of scientific farming. Method demonstrations were held on the farms of cooperating clients.

7) Community meetings were held to teach farm management. Such meetings were discussion groups wherein farmers could also present their problems.

8) News publicity promoted the program. The presentation of information to civic groups gained acceptance and showed progress made.

9) The existing aides did most of the total farm management program while the new aides concentrated on services the farmer wouldn't do himself.

10) Services of manpower and community services in the (CAP) organization helped clientele find employment, or referred him to other agencies. 
11) To summarize: services, counselling, mastitis control, pasture development, referrals, milk sample testing, and counselling on use of credit for operation of the farm, were part of the total farm help program.

\section{Personnel Career Advancement}

The dairy aides began by offering services; in conjunction with in-service training, their capabilities were raised to offer educational services within the same position. They were able to progress to the position of dairy aide counselor upon completion of course work, based upon demonstrated capability, as high school equivalency was to be attained.

Upon taking college classes, the counselling aides were able to progress into jobs under various agribusiness categories or D.H.I.A.

\section{NATURE OP THE PROBLEM}

Millions of dollars have been spent annually for funding and refunding programs designed to combat poverty. Those funds represented investment by taxpayers of the United States in an effort to improve the quality of life for over 25 million Americans who were categorized as poverty stricken. As with most any investment venture 
some worthwhile measures of return are necessary for the investment to merit continuance. Concomitantly, measures of return aid in selecting among investment alternatives. Objective realization and the degree of objective realization might well be the decision measures in the case of poverty abatement projects.

According to some researchers, there is little evidence that the American people are yet willing to assign a top priority to the war on poverty. Many have speculated future courses of action to be slanted toward expanding more productive programs and phasing out the less productive ones. Hence, there is need for evaluating present programs as a means of determining their successfulness in achieving established objectives (serving the need of the people), and assessing the likelihood of their future existence.

Phillips ${ }^{3}$, a proponent of institutional evaluation, posits that "healthy institutions keep growing, change directions to meet new needs, abandon old functions and take on new ones, become involved in controversy, and win more than they lose".

3Phillips, H. S., Guide for Development, Institution Building and Reform. (Frederick A Praeger Publishers, New York, Washington, London, 1969). 
III. STATEMENT OF OBJECTIVES

It was the purpose of this study to determine the effectiveness of the Ozark Dairy Management Component in realizing its stated goal.

Specific Objectives:

1. To outline specific characteristics of, (a) the area in which participants resided, (b) the Ozark Dairy Management Component, and (c) the participants in the Ozark Dairy Management Component.

2. To compare some of the Dairy Management Components objectives with documented performance of the participants.

3. To determine benefits of the component as perceived by participants.

IV. SIGNIFICANCE OF THE STUDY

It was felt that the findings of this study could be useful in the development and implementation of future programs in the Ozarks and similar economically disadvantaged regions. Attainment of the study objectives, it was felt, could provide some bases for decision making in regard to future direction of the Ozark Dairy Management Component. 


\section{METHODOLOGY}

The following principles provided focal confine for the analysis:

--Evaluation of the project should relate, as closely as the data would allow, to the project's objectives. --Evaluation should assess both project product and project process.

--Project evaluation had to allow for the dynamics of change.

--Evaluation should focus on what has been done as well as what has not been done.

--Project evaluation should be concerned primarily, if not exclusively, with key indicators of success or non success.

Although temporal and monetary factors disallowed desired comprehensiveness and strict adherence to the above principles, they served needed directional purpose.

\section{Population And Sample}

The population of this study consisted of approximately two-hundred "low income" dairy farmers who participated in the Ozark Dairy Management Component during the years 1966 through 1970. Those farmers were selected for participation, on the basis of minimum income requirements 
as set forth by $\mathrm{OEO}$ guidelines. The population was finite, all participants were on record in a Dairy Herd Improvement Association Directory maintained in the Dairy Science Department, University of Missouri.

A subpopulation of 75 participants who also participated in the DHIA "weigh a day a month" program (also known as owner sampler test) was selected as the sample to be used in this study. The seventy-five dairymen who were selected were not interpreted as either a random or representative sample of all Dairy Component participants. They were the group of farmers for whom data were available.

Further narrowing of the sample was caused by the decision to subdivide the seventy-five selected dairymen into: (1) participants who had been with the program less than three years and (2) participants who had participated three or more years. Only limited study was made of the group with "less than three years participation. The "less than three years" group was made up of several different situations. It included:

1) Participants who had entered the program in the last two years.

2) Participants who had graduated from the program in less than two years.

3) Participants who dropped out of the program. 
Available information showed that those farmers who graduated within two years were nearest to the $O E O$ minimum income guidelines and also, apparently, were the better managers. Those who dropped out within two years participation generally received alternative employment counseling. Many dropouts were engaged in other livestock enterprises and subsequently concentrated upon some alternative to dairying. Other "drop-outs" became employed in other jobs.

\section{Data: Sources And Collection}

Data were gathered from four sources: (1) the Dairy Herd Improvement Association's monthly and annual herd summaries, (2) planning and implementation records of the Ozark Dairy Component, (3) mail questionnaire, and (4) Missouri Agricultural census data and data on Missouri counties.

The primary data source was the DHIA records, obtained from the main collection point at Ames, Iowa in cooperation with the Dairy Science Department, University of Missouri-Columbia. Some information, not specifically pertinent to this study's objectives was collected because of its supportive effect and potential value in future considerations.

There were some errors in the monthly record summaries. This inconsistency was usually due to 
bi-monthly recording of information or no recording at all. Though errors did occur, any profound effect on the analysis was minimized by taking the monthly observations for the next month.

The planning and implementation records of the Dairy Component were examined to determine; (1) the proposed objectives, (2) the program of work, (3) the clientele served, (4) the specific geographic area served, and (5) the amount of funding provided by OEO. These data were basic to an understanding of the program and the evolution of it.

Personal information such as number of years completed in school, investment over past five years, and attitudes regarding the Ozark Dairy Management Component were obtained by questionnaire sent directly to participants.

Census data was used to acquire descriptive data on the area in which the low income dairy farmers resided. Such data, as included in this category, were information on basic resources, migratory trends, education, population and employment.

\section{vI. ORGANIZATION OF THE THESIS}

The remaining portion of this thesis is divided into five chapters. Chapter two (II) is a review of related 
literature. An attempt was made to: (1) identify the what, where, and why of poverty, (2) review impact analysis case studies, and (3) briefly review materials regarding tactics and techniques of project evaluation.

Chapter three (III) contains background and informational data relative to: (1) the study area, and (2) the participants in the ODMC. Information presented regarding the study area covered those variables felt to bear implications regarding the impact of the ODMC.

Chapter four (IV) contains analyses of performance by Ozark Dairy Management Component participants and a report of some findings.

Chapter five (V) contains analysis of investment feasibility. A short explanation and application of the Internal Rate of Return analysis is included in an effort to determine relative returns, per farmer, to both public and private investment spending.

The final chapter (VI), contains a summary of findings, a report of the conclusions, and some recommendations. 


\section{REVIEW OF RELATED LITERATURE}

Literature relating to the topics of: (1) poverty, delineation and alleviation, (2) impact analysis case studies, and (3) feasibility analysis were reviewed to give the writer a more enlightened perspective of each topic and its potential relationship to the study of public spending for the dairy program.

I. POVERTY, DELINEATION AND ALLEVIATION

Many prominent researchers have attempted to define poverty. Some approach poverty from an economic standpoint i.e., level of income, while others approach it from both the social and economic standpoints. Jones ${ }^{4}$ points out that poverty has not yet been rigorously explained, and as a result, no agreed upon solution has been found. He suggests that in addition to the lack of income, poverty is the lack of access to a respectable position in society and the lack of power to do anything about it. It (poverty) is insecure and unstable homes and a wretched

${ }^{4}$ Jones, B. Walton, "Nature and Extent of Rural Poverty," Papers on Rural Poverty. Agricultural Policy Institute, School of Agriculture and Life Science, North Carolina State University. 
existence that tends to perpetuate itself from one generation to the other. Ornati ${ }^{5}$ related poverty to income level. He established the following categories with the indicated minimum income levels: (1) Minimum subsistence-$\$ 2,662.00$; (2) Minimum adequacy-- $\$ 4,348.00$; (3) Minimum comfort--\$5,609.00. According to this definition 26 per cent of the United States households were below subsistence at that time.

The President's commission ${ }^{6}$ offered a vivid description of poverty:

Many of the disadvantaged people have developed a culture of poverty...the poor think differently, they have a different set of values...The poor tend to be fatalistic and pessimistic because for them there is no future; everything is today. They do not postpone satisfaction. When pleasure is available they tend to take it immediately. They do not save, because for them there is no tomorrow... it is the logical and natural reaction of people living without hope, without a future.

For sometime, it has been contended that poverty existed in "pockets." Contrary to this contention, the Rural Poverty Commission? found that "poverty refuses to stay in pockets," although there are areas with heavy

\section{Sornati, 0scar. Poverty Amid Affluence. New York:} The Twentieth Century Fund 1966.

6The President's National Advisory Commission on Rural Poverty. The People Left Behind. Issued September 1967. Washington D. C.

\section{? Ibid.}


concentration of poor. Keyserling ${ }^{8}$ noted that of the approximately 34 million poor in the United States in 1960, 44 percent lived in the South and 15 percent lived on farms. Some demographic studies by the USDA seem to be indicative of poverty concentration. Two such studies are "Human Resources in the Rural Mississippi Delta", and "An Economic Survey of the Ozark Region."10 These two studies report poverty concentration in six states and in two well defined geographic regions. These findings do not give support to the Poverty Commission's contention of poverty's refusal to stay in pockets. Pinpointing the direct causes of poverty is a difficult, if not impossible task. However, many writers have attempted to delineate the causes and have thus far succeeded in determining certain economic and sociological conditions co-existent with poverty. It is suspected that if one attempted to investigate the causes of poverty, in

8 Keyserling, Leon $H$. Progress or Poverty. Conference on Bconomic Progress, 1001 Connecticut Avenue, N. W. Washington, D. C., December 1964.

${ }^{9}$ Crecink, John C. and Steptoe, Roosevelt. Human Resources in the Mississippi Delta...With Emphasis on the Poor. (Agricuitural Bconomic Report No. TO) United States Department of Agriculture-Bconomic Research Service. January 1970.

10 Bender, Lloyd D, and Jordan, Max F, An Economic Survey of the ozark Region." (Agriculturai Bconomic Report No. 97) Economic Research Service-United States Department of Agriculture July 1966. 
one single incidence, he could find himself pursuing a multi-directional and cyclical path embedded in a plethora of infused-forces reacting and interacting with and upon the poverty stricken individual. Such makes poverty causes difficult to define and, moreover, difficult to alleviate. West 11 offers the following as being among the causes of poverty in the United States: (1) rapid technological development in agriculture, (2) underinvestment in human resources, (3) underemployment, (4) distribution effects of price and income support for farmers, and (5) discrimination. He pointed out that though some of these causes are generally related, they should be considered separately. Their seriousness would be less if the economic system was functioning more properly.

Inadequate education and lag of services are causes of rural poverty. 12 According to Ratchford 13 "the well documented lag in services to rural areas by both federal and state governments should be corrected, as such

11 West, Jerry G. "Evaluation of the People Left Behind." Papers on Rural Poverty. Agricultural Policy Institute, School of Agriculture and Life Science, North Carolina State University.

12 Ratchford, Brice C. Role of State and LandGrant University Extension Services $\frac{1 n}{1 n}$ BIImInatin R Rural Poverty. University of Missouri sxtension Division Pubilcation, November 1967, Columbia, Missouri.

13 Ibid. 
bears great implications on rural poverty alleviation. Lag alleviation should result in better jobs for youth of all ages, better community planning, and better community services and facilities."

A series of studies on human resources in the rural Mississippi Delta with emphasis on the poor have sought answers regarding what and why of economic disparity. On the "why" question, Bryan and Bertrand ${ }^{14}$ tested the assumption that low rates of social participation and high rates of fatalism among the poor lessen their chances to move out of poverty. The researchers conducted a study covering 42 Mississippi Delta counties. The results revealed that "contrary to prevailing assumptions, propensity for change did not relate to either lower rates of social participation or higher rates of fatalism among rural poor." Like the relatively affluent, social paricipation and fatalism in no way affect an individuals potential for upward social mobility.

Bender, Hobbs and Golden ${ }^{15}$ posited that the

${ }^{14}$ Bertrand, A. L., Bryan, C. H., Propensity to Change Among Rurai Poor in the Mississipp DeIta: $A$ Study of the Roots of Social Mobility. (Agricultural Economics Report No-185) B.R.S.-U.S.D.A. In cooperation with Loulsiana State University Experiment Station, June 1970.

15 Bender, Lloyd $D_{\text {, et al. Congruence Between }}$ Aspirations and Capabilities of youth in a tow Income Area. (Reprinted from Rural Soc1010gy, Volume 52, No. 3 , September 1967), pp. $278-289$. 
aspiration for occupational attainment of youth in low income areas is not dampened by incidence of poverty. The level of occupational aspirations of senior youth in low income counties in Arkansas appeared to be similar to those in high income industrial counties. The major conclusions were that occupational capabilities and aspirations were not closely related, and that a lack of capability may be a more limiting factor than aspiration levels in the occupational achievement of rural youth. Other subsequent conclusions drawn on the basis of their findings were that work experiences in a low income rural environment do not provide an adequate basis for testing the reality of aspirations. The youth expected to change their capability levels by means of additional training, or they assumed their education and training to have been comparable to that of most other students. Based upon the results of the foregoing studies one could reasonably infer, as those researchers did, that underdevelopment and poverty is not solely a function of lack of motivation and aspiration.

\section{IMPACT ANALYSIS CASE STUDIES}

Bconomic impact case studies usually adhere to identifying and measuring monetary impacts of projects. Often these studies provide retrospective analytical knowledge upon which to base and plan future courses of 
action. The review of some impact analysis case studies aided the structuring of this study.

In analyzing the impact of public spending on a

rural Missouri area, the Economic Research Service 16

pursued the following methodological guidelines:

1. All data pertaining to public spending were obtained from the comptroller's office and other reliable personnel at the institution whereupon the spending was concentrated.

2. Demographic data were obtained from secondary sources.

3. Socio-economic data were obtained by mail questionnaire administered to participating inhabitants of the study area.

4. The impact measure was determined through the use of an employment multiplier which estimated the change in employment when new jobs were created.

The findings showed the spending to have "had little direct impact upon the area's agricultural economy, as little of the agricultural production was consumed at the

16 Holmes, 0. W. The Impact of Public Spending in a Low Income Rural Area, A case study of Fort Leonard Wöod, Vissouri. ( Agricuitural Economics Report No. I35). washingtion, D. C., June, 1968, p. 24 . 
institution (Fort Leonard Wood.)" However, it was noted that job availability enabled farmers to become part-time farmers and hold part-time or full-time jobs off the farm. Other findings were: (1) population within the area counties showed an increase in the net out migration figures; (2) private housing showed little or no impact; and (3) private businesses showed no increase as most goods and services needed could be purchased within the fort's confines.

Hagerman and Braschler ${ }^{17}$ in a study of the impact of industrialization on local government adopted a descriptive and analytical approach. Using the pre-industrial status as a base, the researchers analyzed available financial records and production data for 1953-1964. Data gathered, covered such components as; (a) position in the economy of the area, (b) banking and financial structure, (c) general economic situation, (d) population characteristics, (e) labor force and employment, (f) agricultural sector, (g) personal income, ( $h$ ) new construction, and (i) vacant homes.

$$
\text { Impact was categorized as; (1) impact on the }
$$

17 Braschler, C. H. and Hagerman, D. L. An Analysis of the Impact of Industrialization on a Small Town: A case Study of Ava, Missouri. Research Burletin No. 910, University of Vissouri Agricultural Bxperiment Station, Columbia, Missouri, July 1966. 
business economy, (2) impact on city government, (3) impact on county government, and (4) impact on schools. The impact felt in category one was attributed to agricultural prices, construction and new money. New businesses were formed and old ones remodeled as industrialization progressed. (It was suspected that prices would come into play in the analysis of the Ozark Dairy Management Component as income from the sale of milk produced was one of the primary variables selected for observation. It was assumed that the income variable would be strongly dependent upon production level, milk quality, and prices offered.)

The city government, according to the findings of Hagerman and Braschler, was subsequently able to provide more services and utilities on more efficient bases. Also the ability to pay for increased services and utilities was reported to have increased substantially with the industrialization. During the period of industrialization it was noted that substantial amounts of state and federal aid were used in the improvements noted above.

County government was rated as having realized increases in operating expenses. However, it was posited that increased county receipts were not industrially associated. 
The schools realized larger enrollments than would have been realized otherwise. Increased property valuation increased the ability to pay for education. The more general approach as followed by Hagerman and Braschler was typical of the "Bconomic Base" type analysis. As defined by Tiebout, 18 the economic base of a community consists of those activities which provide the basic employment and income on which the local economy depends. An "economic base study" identifies the basic sources of employment and income and provides an understanding of the source and level of all employment and income in a community. ${ }^{19}$ The primary objective of an economic base study is to develop information which will help a community solve local problems, make better decisions about matters that will enlarge economic opportunities for its citizens, improve their welfare, and make it possible for them to contribute to national growth. Assessment of resources via socio-demographic research and economic base analysis ought to be ex-ante considerations of community development and improvement organizations and community citizens as they strive to dislodge underdeveloped

18 Tiebout, Charles M. "The Community Bconomic Base Study," (Supplementary paper No, 10 published by The Committee for Bconomic Development, December 1962). 19 Ibid. 
communities from the grip of economic disadvantage.

Although some of the impact analysis studies focused upon the immediate and measurable impact weighed by the various projects, much is to be said about motivational forces. Hoover 20 in the analysis of the effect of industrialization in Braxton County, West Virginia noted that in addition to the employment and income creating effect; "with the success of the first project (The Particle Board Plant) the people of Braxton County began to seek more industry for their area." Negotiations were reported to have begun for the acquisition of a rubber fabricating plant and a furniture manufacturing plant. It appeared that "Braxton County has undergone major recent social and economic changes. The county has had some growth in manufacturing, construction, tourism and in retail and wholesale trade." The county's three high schools were reported to have been consolidated into one. Steward 21 gave indications of the motivational impact when reporting that in addition to moving toward its

20 Hoover, Herbert. Rural Industrialization in West Virginia: A Case Study of a Plant in Braxton County, West Virginia. Teconomic Research Service-United states Department of Agriculture, Washington, D. C.

${ }^{21}$ Steward, Donald D. Impact of Bconomic Opportunity Ioans on Rural Residents, South Carolina, The ozarks, Nississippi Delta. Bconomic Development DivisionB.R.S. (Report No. 151 ). 
specified objectives, an economic opportunity loan project enhanced a willingness among participants to take special training to improve their income earning abilities. Another impact felt from the OBO loan project was the substantial increase in net cash family income for the borrowing participant. It was reported in some instances that using the loan to refinance prior debts enabled the borrower to retain possession of income-producing assets. Moreover, the liberal repayment terms of the loans along with refinancing prior debts enabled the more extensive use of existing income for family living purposes. The Ozark Dairy Component had as a major objective to assist in securing financing, whereby the dairy farmers could utilize their incomes more freely in mitigating indebtedness, and raise their level of net income. With the backing of the local CAP organization, it was felt that the farmers could obtain favorable credit extensions and modest repayment terms. This study investigates aspects of component participants' credit situations.

\section{PEASIBILITY STUDIES}

Economic feasibility analysis provides for viewing rural development (anti-poverty) projects from a costreturn standpoint. Valuation of all the inputs and all the subsequent end results (returns) is an inherent problem 
of the benefit-cost approach. Further, the results are strictly quantitative and not qualitative. Subjecting a specific project to evaluation by sociologists and then to benefit-cost evaluation by economists might yield strikingly different answers.

Existing methods of estimating economic impacts associated with resource development programs are believed to be deficient 22 because of (1) lack of suitable secondary data and expense of obtaining primary data; (2) difficulty in measuring income and employment effects of relatively small expenditures associated with local impact projects; and (3) the problem of accurately attributing local impacts independent of regional and national economic activity. It is the writer's opinion that even though deficiencies do exist, analysts must continue to estimate impacts of poverty programs. Moreover, results based upon sound economic assumptions are better than no results at all. Perhaps the continued pursuit and extension of present methodologies of analyzing resource development projects and their impacts will ultimately lead to the discovery and development of less deficient methodologies.

22 Stewart, Clyde B. "Secondary Benefit Bvaluation in Federal Reclamation Programs." Secondary Impacts of Public Investment in Natural Resources. (Pubircation No. II7? U.S.D.A.-B.R.S., September, 1968). 


\section{Benefit Cost Analysis}

"Benefit-cost analysis can be characterized as the collection and organization of data relevant by some conceptually meaningful criteria to determine the relative preferredness of alternatives." 23 Specific uses of benefit-cost analysis in the U.S. and Canadian governmental manpower policies has occurred in the evaluation of returns to education, and in connection with water resource development. 24

The benefit-cost analysis can be applied to projects either as B-C (benefits minus costs) or B/C (the ratio of benefits to costs.) The former favors large projects, the latter is the recommended basis for comparing projects. The analysis is usually done under the assumptions; that the benefits and costs are of uniform nature, and when comparing projects, (2) that the life spans of projects are the same. ${ }^{25}$ Assumptions are also made regarding the level of uncertainty of benefits envolved. This analysis serves both for satisfaction and for relative evaluation of projects.

${ }^{23}$ Smith, Stephen C. and Castle, B. N. Bconomics and Public Policy in Water Resource Development. Ames: Iowa State University Press, 1965.

${ }^{24} \mathrm{Smith}$, 오. cit.

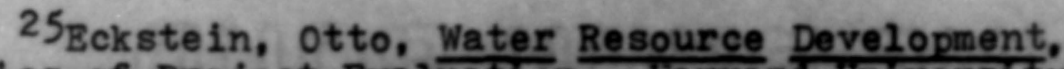

Economics of Project Bvaluation. Rarvard University press Cambridge Massachuset $t$ ts, 1968. 
Formulation of $B / C$ Ratio

Let:

$B=$ Benefits received annually

$C=$ Costs per year

$\mathrm{K}=$ Fixed investment

$0=0$ perating, maintenance, and routine replacements incurred annually

$i=$ Interest rate

$r=$ Rate of Return

$\mathrm{T}=$ Amortization rate

then: Present values of total cost $=\sum_{t=1}^{T} \frac{0}{(1+1) t}+K$

So: $B / C=\left[\sum_{t=1}^{T} \frac{B}{(1+i) t}\right]\left[\sum_{t=1}^{T} \frac{0}{(1+1) t}+1\right]^{-1}$

Since the above is the overall benefit-cost ratio, the $B / C$ ratio on the annual basis requires division by: 26

$$
\sum_{t=1}^{T} \frac{1}{(1+1) t}
$$

Therefore:

$$
B / C=\frac{B}{O+K}\left[\sum_{t=1}^{T} \frac{1}{(1+1) t}\right]^{-1}
$$

let: $\sum_{t=1}^{T} \frac{1}{(1+1) t}=\operatorname{AIT}$ (i.e., some constant) 
then: $B / C=B / 0+A I T K$

Inherent also in benefit-cost analysis are questions regarding price specification, interest rate, period of analysis, and method of depreciation. Those questions are discussed next:

Risks--Some adjustments for risk are required. A major source of risk in public projects; for example, power programs; is attributed to technology, i.e., the advancement in technology would tend to make currently constructed plants obselete. Another source can be attributed to the nature of unstable demand for specific output. Generally, risk conditions can be injected into benefit-cost analysis in three ways: (1) by shortening the period of analysis; (2) by including a risk factor in the interest rate; and (3) by making safety allowances either in the cost or benefit side of the expression B/C. ${ }^{27}$

Depreciation--In federal projects, a method that calls for sufficient annual payments into sinking funds in order to replace original equipment is used. This method of depreciation, i.e., amortization amounts to less depreciation than the straight line method which has been popular in private business. 
Interest rate--"The subcommittee accepts without qualification the proposition that consistent discounting procedures and appropriate interest rate policy must be adopted through the federal government if wise and economic investment decisions are to be made." 28 Some suggested rates have been: (a) the rate of return on "good-private investment;" (b) the opportunity cost of capital; (c) the social rate of time preference.

\section{Internal Rate of Return}

The internal rate of return is the anticipated rate of return internally to the project. It (IRR) is closely related to the fully-discounted benefit-cost ratio for the same project. The $B / C$ ratio is 1.0 when the investment and net benefit schedules are discounted at the rate exactly equal to the IRR. The B/C ratio is less than 1.0 at any discount rate higher than the $I R R$. The $B / C$ ratio is greater than 1.0 when calculated at any discount rate lower than the IRR.

The internal rate of return is a measure of potential return to capital investment in a project based on the time flow of money into and out of the project. It is the annual compound discount rate which makes the present

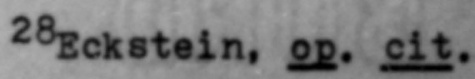


value of the investment schedule equal to the present value of the net benefit schedule. ${ }^{29}$ The IRR can be calculated by solving for (i) in the following formula:

$$
\begin{aligned}
& I_{0}+I_{1}(1 / 1+i)+I_{2}\left(1 /(1+i)^{2}\right)+\ldots I_{n}\left(1 /(1+i)^{n}\right)= \\
& B_{0}+B_{1}(1 / 1+i)+B_{2}\left(1 /(1+i)^{2}\right)+\ldots B_{n}\left(1 /(1+i)^{n}\right)
\end{aligned}
$$

where:

$I=$ net investment in each year

$B=$ net benefit in each year

and:

$0,1,2, \ldots \ldots$ n represent the year dating from the present.

One advantage of the IRR is that it requires a minimum of assumptions and judgements. It is not necessary to assume an interest rate and calculate interest charges. It is not necessary to assume depreciation schedules and calculate annual depreciation charges. No assumptions regarding inflation are required. It is also not necessary to discount future receipts or expenditures. It is not necessary to assume a given percentage of equity or any terms of financing. 30

29 phillips, Richard, "Internal Rate of Return." Unpublished paper on Project Peasibility Analysis. Agricultural Research Service, Manhattan Kansas, 1970. ${ }^{30}$ Ibid. 
The two sets of data necessary to calculate the IRR are a schedule of total capital investment and the schedule of net benefits over the planning period of the project. However, there are a number of standard rules that should be followed.

The primary purpose of the $B / C$ ratio and IRR tools in the feasibility analysis for any project or group of projects is to measure the economic potential, normally defined as the expected return on capital investment. 31 In order to accomplish the primary objective of measuring the economic potential of a project, feasibility analysis must; (1) estimate potential as accurately as possible, (2) closely approximate reality, (3) be sensitive to the major factors that will affect the investment requirements and profits and loss if the project is carried out, and (4) avoid unnecessary refinements which will have little to do with actual potential investment requirements and actuai annual net earnings.

Greiner ${ }^{32}$ in determining the economic feasibility of a feeder pig component, of the Ozark Bconomic Opportunity Commission, employed both benefit cost and internal

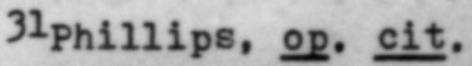

32 Greiner, Frank. "The Economic Peasibility of a Feeder Pig Component Project." A Masters Degree Paper. College of Agriculture, University of Missouri-Columbia, Missouri 1970. 
rate of return analyses. The results showed that after only two years of the components operation, cumulative returns were greater than cumulative investment. The $\mathrm{B} / \mathrm{C}$ coefficients obtained ranged from .80 to 2.11. Inherent in the analysis was the necessity of making strong assumptions relative to the valuation of benefits and costs.

In chapter five of this study underlying theory and techniques of both the "Benefit Cost Ratio" and "Internal Rate of Return" will be employed. The use of above techniques will aid in determining past and future potential effect of investment outlays of the pub2ic and the low income dairy farmers involved. 
DEMOGRAPHIC AND SOCIO-ECONOMIC CONSI DERATIONS

\section{THE STUDY AREA PROFILE}

The area with which this study was concerned was a subsection of the Ozarks Economic Development Region 33 . The Economic Development Region originally included 44 counties in Arkansas, 44 counties in Missouri, and 37 counties in Oklahoma. The dairy project of interest was limited to six contiguous Southwest Missouri counties (Christian, Dallas, Greene, Hickory, Polk, and Webster).

The area is located in the Ozark Plateau sub-region. The sub-region covers most of the southern half of Missouri and part of northern Arkansas. The interior of the plateau is separated from the surrounding low-lands by a belt of rough, hilly land. The upland soils are not naturally fertile and the major series contain stone and gravel. Where level, the uplands frequently have a hard-pan subsoil that creates poor internal drainage. The average annual rainfall is 48 inches, indicating a moderately wet climate. Snow and sleet total twelve inches annually. The winters

33Kuehn, John Allen. "Highway Impacts on Ozarks Incomes and Employment." Unpublished Ph.D. Dissertation, University of Missouri, Columbia, 1970. 
are long with temperatures in the mid-thirties, and summers average 75 degrees ${ }^{34}$.

The major trading area serving the counties is Springfield, Missouri. The per county average land area ranges from 410 to 642 square miles. When compared to the sizes of the 3,135 United States counties, land area in Christian, Dallas, Hickory, and Webster counties is less than the average U.S. county. Greene and Polk counties are larger than average. (County area identified in Figure 1). Data regarding land area in the six counties are presented in Table $I$.

\section{Agricultural profile}

The United States Census Bureau defined a farm as a place comprising at least ten acres of land devoted to farming or selling at least $\$ 50$ worth of agricultural products annually35. According to the definition, 10,318 farms were enumerated in the six county area in the 1964 Agricultural Census Report. Table I contains data regarding proportions of land in farms, number of farms, farm size, and proportions of farms with gross farm sales less than $\$ 2,500$ for the six counties studied. The proportions of

34 office of Bconomic Opportunity Information Center, "Community Profiles," (An indepth look at Missouri county economic base and resources) 1966.

35United States Bureau of Consus, Unitod States Census of Agricuiture (Missouri volum 1,7 


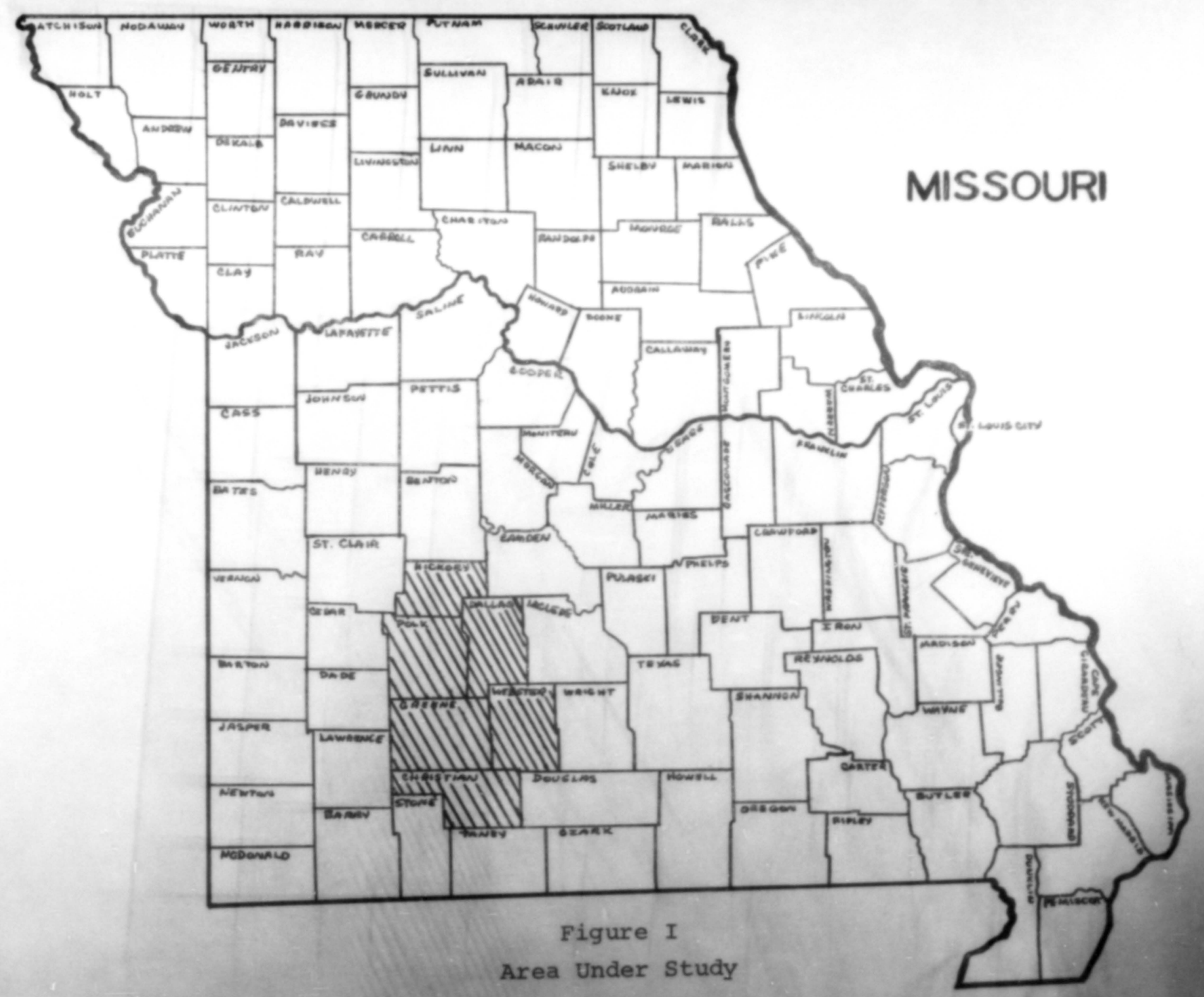


LAND AREA; PROPORTIONS OF LAND IN FARM, FARM SIZES; NUMBERS AND INCOMES; AND LEVEL OF

LIVING INDICES BY COUNTY IN

THE AREA OF STUDY

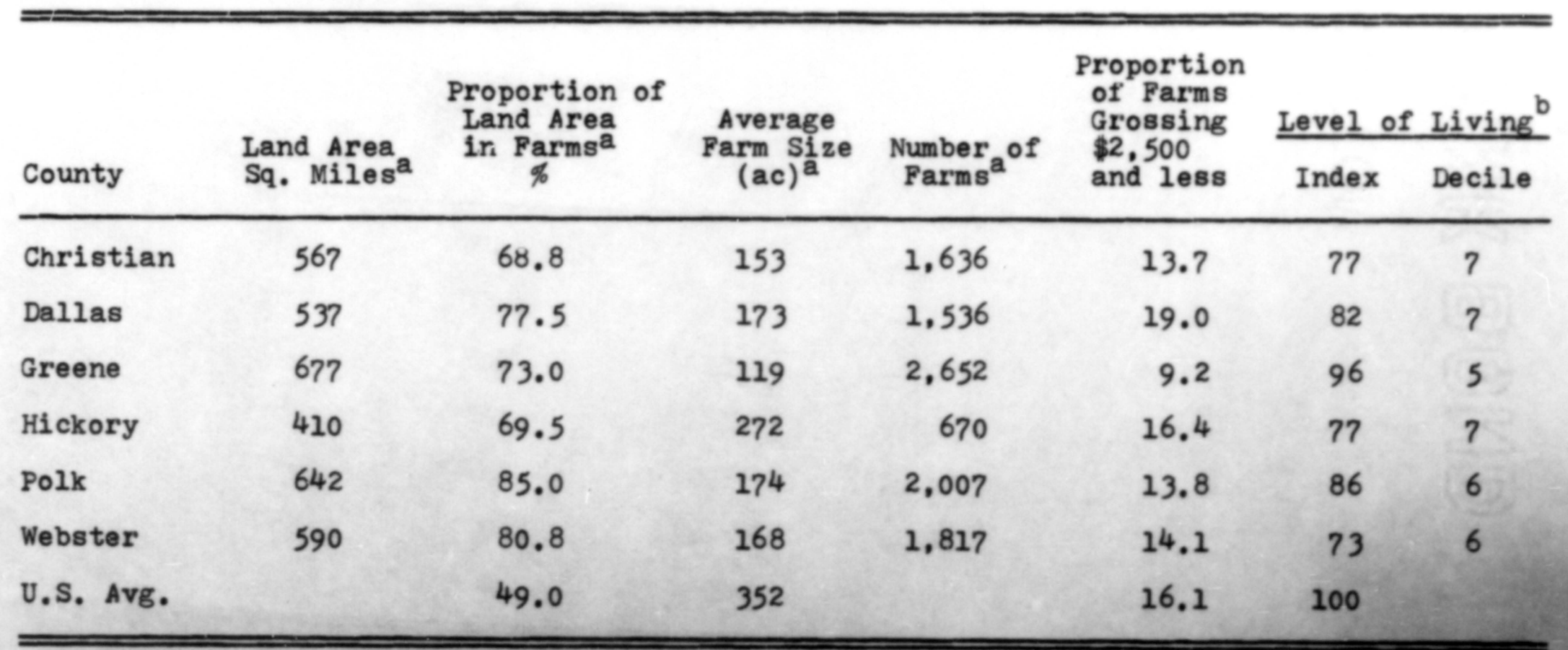

anited States Bureau of Census, United States Census of Agriculture (Missouri Volume 1, Part 17), 1964.

${ }^{b}$ Community Profile Reports, 1966. 
land in farms ranged from 69 percent to 85 percent. All counties had a greater proportion of land devoted to farming than the United States average (49 percent). Average farm size ranged from 119 acres to 272 acres and was substantially smaller than the average U.S. farm size of 352 acres.

The proportions of "small farms" and "Class VI commercial farms" in the six counties was interesting. By United States Census Bureau definition, a small farm was a place having sold more than $\$ 50$ worth of agricultural products yearly and comprised of less than ten acres of farm land. 36 According to this definition, small farms comprised about 2 percent of all farms in the six county area. The range was from 1 percent to $?$ percent. of the six counties, only Greene county had a proportion of small farms as great as the average United States county (? percent).

Class VI commercial farms were defined as places which produced agricultural products, in a given year, whose value was less than $\$ 2,500,37$ Additionally, the farm operator could not have worked off the farm more than

\section{${ }^{36}$ United States Bureau of Census, op. cit. 37 Ibid.}


one-hundred days a year. The percent of farms classed as Class VI commercial ranged from 9 to 19 percent in 1964. For the United States, 16 percent of the farms were Class VI commercial farms. Since gross farm sales on Class VI farms were less than $\$ 2,500$, it is likely that a large share of the operators were low income farmers and met OBO guidelines.

The farm-operator family level of living index has been suggested as a general measure of economic well-being of the farm population in a county. Based on the average value of land and buildings, average value of agricultural products sold, and the percentage of farms with automobiles, home freezers, and telephones, the index is constructed such that the average of all counties in the United States in 1959 provided a base index of 100.38 Data on the farm-family level of living index are presented in Table I. The counties had indices ranging from 52 to 68 , lower than the average United States county. The decile

38 office of Bconomic Opportunity Information Center. "Community Profile" 1966. 
ranks ranged from five to seven. The observed index values and decile ranks suggested that the six counties were populated by farmers who had lower levels of living than the average United States county.

\section{Population: Some Characteristics}

During the two decades of 1940-1950, 1950-1960, all but Greene county experienced a decline in population. The decline ranged from 0 to 16 percent. It has been speculated that the changing structure in the area's agriculture and the outward mobility of the young contributed to the declining populations.

During the period 1960-1970, only Hickory county experienced continued population decline (-1 percent). Converse to the trend of the 1950-1960 decade, most counties showed substantial population gains. The rates of positive change varied from $?$ to 22 percent. It is possible that the gain in population can be associated with the advent of tourism and other job creating enterprises. Data on population trends are presented in Table II.

\section{Area Age Profile}

Statistical data regarding the age profile within the six county area are presented in Table II. The 1960 median age within the counties varied between 31 and 40 years. The percentage of population between ages 18 
POPULATION AND POPULATION PROFILE FOR THE SIX COUNTIES FOCUSED UPON BY THE STUDY

\begin{tabular}{|c|c|c|c|c|c|c|c|c|c|}
\hline \multirow[b]{2}{*}{ County } & \multirow[b]{2}{*}{ Rural } & \multirow[b]{2}{*}{ Urban } & \multicolumn{2}{|c|}{$\begin{array}{l}\text { Change in } \\
\text { population }\end{array}$} & \multirow{2}{*}{$\begin{array}{r}\text { Age } C \\
\text { Median }\end{array}$} & \multirow{2}{*}{\multicolumn{3}{|c|}{$\begin{array}{l}\text { Characteristics }(1960) \\
\text { Less } \\
\text { than } 18-65 \quad 65 \\
18 \text { yrs. years and over }\end{array}$}} & \multirow{2}{*}{$\begin{array}{l}\text { Nedian } \\
\text { years } \\
\text { schooling } \\
\text { completed }\end{array}$} \\
\hline & & & 1960 & 1970 & & & & & \\
\hline Christian & 12,124 & -- & -0.40 & 22.4 & 33.2 & 34.0 & 52.1 & 13.9 & 8.9 \\
\hline Dallas & 10,054 & -- & -10.40 & 7.9 & 39.6 & 31.0 & 51.5 & 17.4 & 8.6 \\
\hline Greene & 31,589 & 121,340 & 20.50 & 21.1 & 30.8 & 32.4 & 55.9 & 11.9 & 10.7 \\
\hline Hickory & 6,634 & -- & -16.20 & -0.8 & 40.4 & 30.3 & 51.8 & 17.6 & 8.6 \\
\hline Polk & 10,646 & 4,769 & -14.40 & 12.1 & 39.6 & 28.6 & 53.3 & 18.1 & 8.8 \\
\hline Webster & 12,601 & 2,961 & -8.80 & 13.2 & 34.7 & 33.9 & 50.6 & 15.5 & 8.6 \\
\hline $\begin{array}{c}\text { Missouri } \\
\text { Avg. }\end{array}$ & 12,165 & 28,502 & 18.80 & 8.3 & & & & & 10.6 \\
\hline
\end{tabular}


and 65 was greater than 50 percent but less than 56 percent for all counties. Such data reflects the relative proportions of county populations which could be assumed available for labor force participation. Data showing proportions of populations greater than 65 years of age and less than 18 years of age are also included in Table II. Those respective age statistics give some indication of the support burdens of the counties in regard to old age retirement and expenditures for education. Proportions of populations less than five years of age for the six respective counties ranged below 12 percent. Over the period (1950-1970) most counties experienced some fluctuation in median ages and in proportions of populations in various age categories. Greater fluctuation occurred in the 65 and over age category, with most counties having shown a substantial increase in that age segment over the twenty years.

\section{Status of Area Poverty}

As suggested in chapter two, poverty within an area, region, or even the United States, as a whole, is somewhat difficult to define. As in most problem areas, research and political and social strategists have identified factors which are most often concomitant with poverty ubiety. Those factors are fundamental to the 
identification and alleviation of poverty and its causes.

Table III presents data regarding poverty indicators for the six county area focused upon by this study. The proportions of families within the counties receiving incomes below the Social Security Administration's poverty guidelines varied from 16 percent to 31 percent. Only Greene county had a lower proportion of families below the Social Security poverty guidelines than the average U.S. county. Median family income for the six counties ranged between $\$ 3,270$ and $\$ 5,370$. Again, Greene county was the only county outside the $\$ 3,000-\$ 4,000$ range.

Unemployment, median school years completed by residents, percentage of residents who failed to complete over four years in school, practicing physicians per 1,000 population units, and percentages of dwelling units housing more than the nation's average of 1.01 persons per room, are other poverty indicators summarized in Table III.

\section{SOME CHARACTERISTICS OF PROJECT PARTICIPANTS}

All participants in the Ozark Dairy Management Component had to meet income guidelines set by the Economic Opportunity Act. They had to be classified as low income families. To be eligible a family's gross income could not exceed $\$ 3,200$ per year for husband and wife with two children. Families with more than two children were 


\section{TABLE III}

POVERTY INDICATORS BY COUNTY AS INDICATED IN COMMUNITY PROFILE REPORTS

$$
\text { (1966) }
$$

\begin{tabular}{|c|c|c|c|c|c|c|c|}
\hline Indicators & Christian & Dallas & $\begin{array}{l}\text { Count } \\
\text { Greene } \\
\end{array}$ & $\begin{array}{l}\text { ties and } \\
\text { Hickory }\end{array}$ & $\begin{array}{l}\text { U.S. } \\
\text { Polk }\end{array}$ & Webster & U. S. \\
\hline $\begin{array}{l}\text { Families with income } \\
\text { below Social Security } \\
\text { cut-off }\end{array}$ & $\begin{array}{c}891 \\
(23.6 \%)\end{array}$ & $\begin{array}{c}804 \\
(30.2 \%)\end{array}$ & $(16.241)$ & $\begin{array}{l}376 \\
(28.5 \%)\end{array}$ & $\begin{array}{l}973 \\
(24.8 \%)\end{array}$ & $\begin{array}{l}1,150 \\
(31.0 \%)\end{array}$ & $\begin{array}{l}1,221 \\
(22,6 \%)\end{array}$ \\
\hline $\begin{array}{l}\text { Median Family } \\
\text { Income }(\$)\end{array}$ & $\$ 3,830$ & 3,270 & 5,370 & 3.355 & 3,486 & 3,440 & 4,630 \\
\hline $\begin{array}{l}\text { Labor force } \\
\text { unemployed }(\%)\end{array}$ & 4.8 & 5.4 & 3.5 & 3.4 & 2.5 & 4.1 & 4.8 \\
\hline $\begin{array}{l}\text { School years } \\
\text { completed (med.) }\end{array}$ & 8.9 & 8.6 & 10.7 & 8.6 & 8.8 & 8.6 & 9.5 \\
\hline $\begin{array}{l}\text { Proportion of popula- } \\
\text { tion who failed to } \\
\text { complete } 4 \text { th grade }\end{array}$ & 7.8 & 10.1 & 5.1 & 5.7 & 6.5 & 10.5 & 7.8 \\
\hline $\begin{array}{l}\text { Practicing Physicians } \\
\text { per } 100,000 \text { population }\end{array}$ & 8.1 & 32.9 & 151.5 & & 52.2 & 36.7 & 61.1 \\
\hline $\begin{array}{l}\text { Percent dwelling units } \\
\text { housing more than } \\
\text { national average }(1.01) \\
\text { persons per room }\end{array}$ & 12.0 & 12.3 & 9.8 & 8.0 & 8.1 & 13.4 & \\
\hline
\end{tabular}


eligible with higher incomes. Under the guidelines an additional $\$ 400$ was allowed for each additional dependent.

Age

The age of participants ranged between 30 and 55 years of age. Most participants could be categorized into the sub-range of from 35 to 48 years of age. The median age of the sample group was 38 years, which was the same as that reported for Christian county.

\section{Educational Levels}

The educational attainment of the participants ranged from eight years to twelve years and greater. Sixty-three percent attained a high school education (Table IV). The group of farmers who participated from only one to two years, in addition to comprising the majority of the sample, was shown to have a substantial proportion of high school graduates. Additionally, 66 percent of those farmers who reportedly attained more than twelve years of education fell in the one to-two-yearparticipant category. All of the participants who were in the project from four to five years had reportedly completed twelve years of school.

\section{Length of Component Participation}

Parmers in the sample participated in the dairy project for varying periods of time. Sixty-eive 
TABLE IV

\section{EDUCATIONAL ATTAINMENT OF THE LOW INCOME DAIRY \\ FARMERS BY GROUPS BASED ON YEARS OF PROJECT PARTICIPATION}

\begin{tabular}{|c|c|c|c|c|c|}
\hline $\begin{array}{l}\text { Years } \\
\text { Partic- } \\
\text { ipation }\end{array}$ & $\begin{array}{l}\text { Eight } \\
(\%)\end{array}$ & $\begin{array}{l}\text { Years } \\
\text { Nine-to- } \\
\text { Eleven } \\
(\%)\end{array}$ & $\begin{array}{l}\text { of School } \\
\text { Twelve } \\
\text { (\%) }\end{array}$ & $\begin{array}{l}\text { Completed } \\
\text { More than } \\
\text { Twelve } \\
(\%)\end{array}$ & Totals \\
\hline $\begin{array}{l}1-2 \text { years } \\
(\mathrm{N}=24)\end{array}$ & 8.33 & 20.83 & 62.50 & 8.33 & 100.00 \\
\hline $\begin{array}{l}3 \text { years } \\
(\mathrm{N}=8)\end{array}$ & 12.50 & 37.50 & 37.50 & 12.50 & 100.00 \\
\hline $\begin{array}{l}4-5 \text { years } \\
(N=6)\end{array}$ & 0.00 & 0.00 & 100.00 & 0.00 & 100.00 \\
\hline $\begin{array}{l}\text { All Sample } \\
(\mathrm{N}=38)\end{array}$ & 7.89 & 21.05 & 63.16 & 7.89 & 109.00 \\
\hline
\end{tabular}


percent of the sample group participated in the component for only "one to two years." Twenty-one percent participated three years and 15 percent participated four to five years.

\section{Size of Operations}

Size of the participants' dairy operations was reflected by: (a) income over feed costs, (b) number of cows in herd and in milk, (c) volume of daily and annual production, both per cow and per herd. Dairy operations ranged from very small to fairly large ( 7 to 63 cows). The average size was about 30 head. Median income over feed costs for the initial year of participation was $\$ 157$ dollars per cow. First year income over feed cost per cow ranged from $\$ 22$ to $\$ 365$. It is normal to expect $\$ 350$ income over feed costs on operating dairy farms. Average daily production per herd in the first year of participation was about 600 pounds. This is consistent with the all Missouri average for herds of this size. Daily herd production was as low as 100 pounds; the high was 1,118 pounds.

Gross milk sales per herd per day ranged from about four dollars to slightly over $\$ 50$. Income over feed costs per day per herd averaged about $\$ 16$ and ranged from $\$ 0.60$ to $\$ 35$. 


\section{PERFORMANCE AND ATTITUDES OF SAMPLE GROUPS}

This chapter summarizes the performance and attitudes of select groups of participants in the dairy component. The sample groups had all used either standard Dairy Herd Improvement Association or Owner-Sampler tests. To be included in the groups used to evaluate changes over time, a participant had to have been associated with the dairy component for at least three years. Participants who received assistance for more than one year were included in a sample to obtain attitudes toward the dairy component and investment information. Thus, the results presented in this chapter are historical in nature and a summary of what happened (or was perceived to have happened) on a select group of dairy farms. The next chapter will make some assessment of future and potential economic impact.

Not all participants began nor terminated participation in the same year. Many participants joined the component in its first year of operation and terminated participation by graduation or "dropping-out", others remained with the project until the last year of operation, 1970, still others joined the project in later years and remained in the project for varying lengths of time. 


\section{INCOME OVER PEED COSTS}

A program objective was to raise income over feed costs per cow to at least $\$ 200$. Average, median, and range statistics on income over feed costs for the 30 farmers are shown in Table v. There was an upward trend in income over feed costs during the three years of participation. Reported change in median income over feed cost per herd revealed an approximate increase greater than 90 percent between the first and second years; and an increase by greater than 30 percent between years two and three. Median income over feed costs per cow, between the first and third years, increased not only to the aspired minimal level of $\$ 200$, but to $\$ 270$. Range of average per cow income over feed cost for herds changed from $\$ 22.00-$ $\$ 365.00$ to $\$ 29.00-\$ 533.00$ between the first and third years of observed component participation. The lower values of the range suggest that some participant herds did not realize a great change in income over feed cost per cow during the three years in the program. However, for the majority of herds there was some income improvement. Average income over feed cost per cow was 35 percent larger in year three than in year one. Part of the income change may be attributed to improving milk prices. Manufacturing milk prices increased by slightly more than 
TABLE V

\section{INCOME OVER FEED COST PER HERD AND PER COW ON AN ANNUAL BASIS FOR THIRTY FARMERS; BY YEARS OF COMPONENT PARTICIPATION}

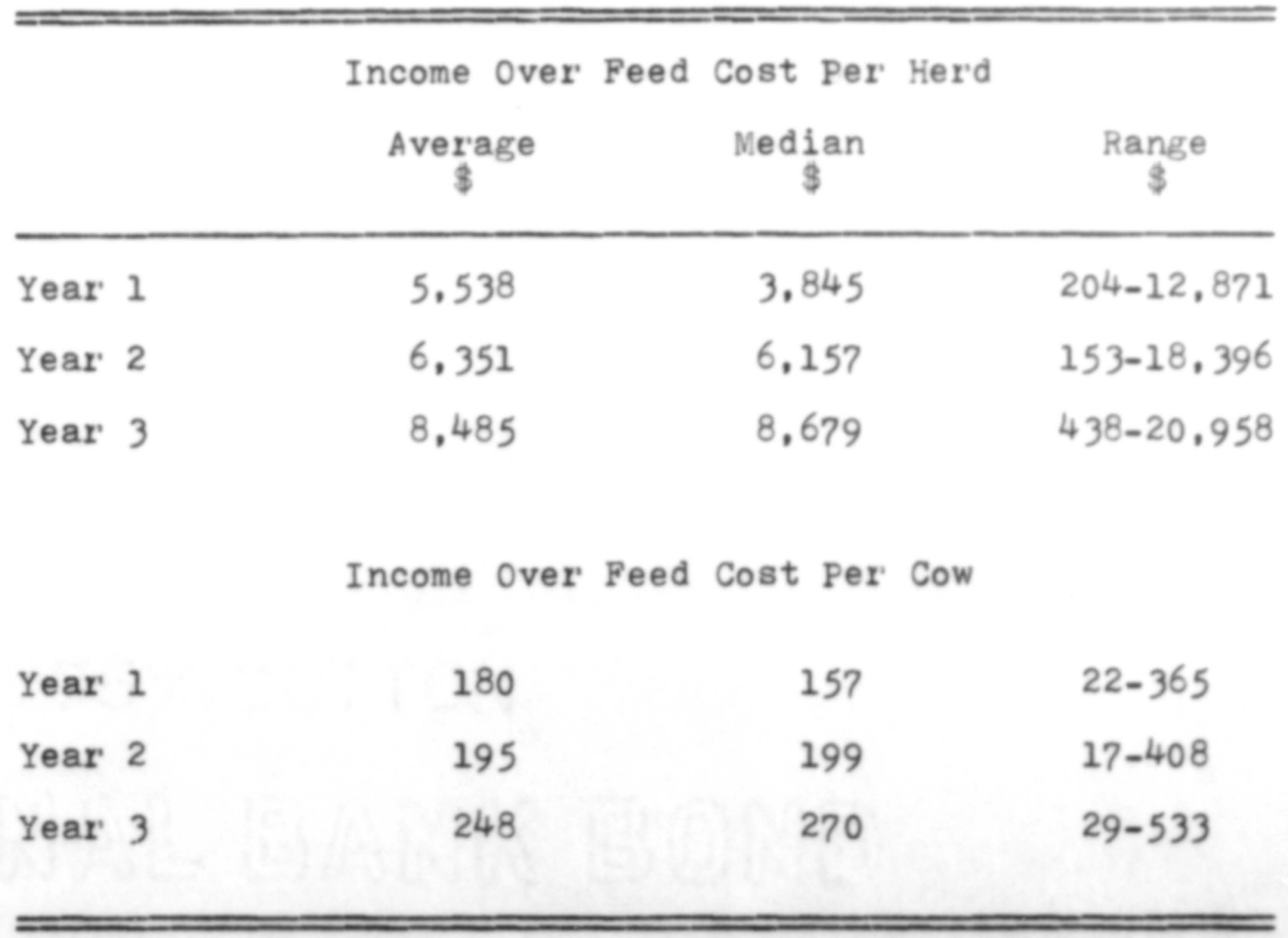


90 cents between 1965 and 1970.

Adjustments in cow number because of culling and replacement practices was another factor affecting income over feed costs. Utilization of test results enabled the dairymen to spot low producers.

It was felt the substantial changes in income over feed cost per herd and per cow typified progress on the part of low income dairy farmers. The share of the progress attributable to project assistance was not determined.

\section{Grouping By Years of Participation}

Though the analysis was essentially confined to three years of component participation, the sample was comprised of farmers who participated three years and longer. The 30 participants were grouped by length of time they had received assistance. The groups and percent in each were: (1) three years participation- -43 percent, (2) at least four years--33 percent, and (3) five years participation--23 percent. The grouping was made to check a hypothesis that participants who received assistance the longest were the least capable managers (or made slower progress). Table vI contains annual data regarding average and median income over feed cost for each participation duration group. In year one of component participation the average and median income over feed coste por cow for groups I and 


\section{TABLE VI}

AVERAGE AND MEDIAN INCOME OVER FEED COST VALUES PER COW AND PER HERD BY YEAR AND BY GROUPS BASED ON LENGTH

OF COMPONENT PARTICIPATION

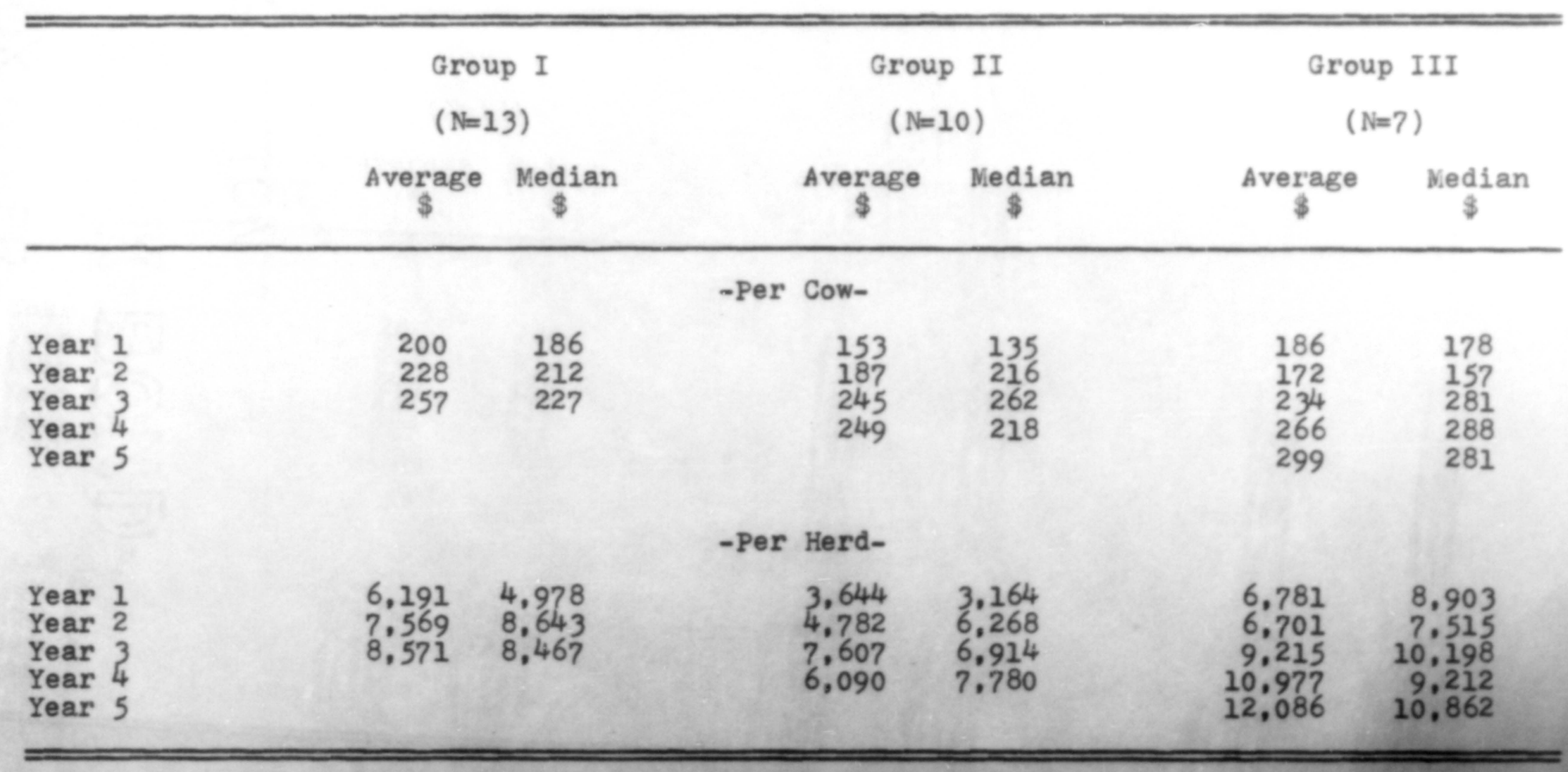


III were substantially greater than for group II. However, by year three the differences between groups were not as marked.

Median yearly income over feed cost per cow was $\$ 186, \$ 135$; and $\$ 178$ for groups I, II, and III respectively, in year one of component participation. In year three, the median incomes over feed costs per cow had risen to $\$ 227$, $\$ 262$, and $\$ 281$ for each of the three groups, respectively. Even deflating for milk price changes, the improvement in earnings per cows was in the 10 to 20 percent range. observation of data regarding income over feed cost for groups II and III for years four and five shows continuous increase in average per cow values. In year four, group II herds realized decreased average income over feed costs while the median value continued to increase. Group III income over feed cost per herd in years four and five showed continued increase while the median value was down in year four to $\$ 9,212$. However, in year five group III median income over feed cost per herd had increased to $\$ 10,862$, a level not achieved in either of the other four years of component participation nor paralled by either of the other two groups.

Overall income over feed cost increased for the majority of farmers in the sample. The highest average income over feed cost value (per herd) was \$12,086 dollars, 
reported for group III in year five. In years three, four, and five, group III farmers, on the average, realized high income over feed cost. It is generally assumed that feed cost make up at least 75 percent of all variable cost. It therefore appears that farmer's who received income over feed cost in the range of $\$ 9,000-\$ 11,000$ dollars have questionable low income status. Moreover, data suggest that many farmers remained with the project after having realized increased income over feed cost above OEO guidelines.

The income over feed cost figures reveal substantial increases for all three groups. On the per cow basis, there was considerably less divergence between groups than is shown by the per-herd figures. The findings failed to give support to the writer's hypothesis that "the longer in the program the slower the progress made."

\section{HERD SIZE}

Several measures of size are often used in comparing the volume of dairy operations. The number of cows in a milking herd is a common comparative measure for dairy enterprises. Along with the number of cows in the milking herd, factors such as (a) percentage of cows in milx, (b) change in herd size, (c) volume of production, (d) feed costs, and (e) value of production were used in this 
analysis to assess and compare changes in the low income dairy farmer operations subsequent to participation in the component project. Moreover, an attempt was made to determine if the objective--"to insure enough cows to justify the dairy farmers' time, equipment and investment," was attained.

\section{Herd Size By Groups}

Table VII contains data regarding number of cows and proportion of cows in milk for groups I, II, and III by year of component participation. Change in cow numbers from year one $\left(Y_{1}\right)$ to the last year of participation $\left(Y_{n}\right)$ was positive for all groups. The percent changes in average cow number per herd for groups I, II and III were 15, 55 , and 10 respectively. Median statistics in addition to reflecting positive change in number of cows per herd, gave the proportions of herds in each group that were either in the lower or upper portion of the range for each year of participation. Thus, in year one at least half of the herds in groups I, II, and III had greater than 30,23, and 33 cows, respectively. Percentage change in median cow numbers from year one to year $\left(Y_{n}\right)$ were 27,48 , and 10 for groups I, II, and III.

The range in herd sizesgives some indication of the size variation within each group. Those values resloet cases of extreme smallness for wone he 
TABLE VII

AVERAGE, MEDIAN, AND RANGE NUMBER OF COWS AND PROPORTION IN MILK BY GROUPS AND BY YEAR OF COMPONENT OPERATION

\begin{tabular}{cccccccccccc}
\hline & & \multicolumn{4}{c}{ Cows } & In Herd & \multicolumn{3}{c}{ Cows In Milk (\%) } \\
Groups $^{a}$ & $Y_{1}{ }^{b}$ & $Y_{2}$ & $Y_{3}$ & $Y_{4}$ & $Y_{5}$ & In & $Y_{2}$ & $Y_{3}$ & $Y_{4}$ & $Y_{5}$ \\
\hline
\end{tabular}

Group I $(N=7)$

$\begin{array}{lllllllllll}\text { Average } & 34 & 36 & 32 & 41 & 39 & 80 & 85 & 82 & 82 & 84 \\ \text { Median } & 30 & 37 & 29 & 39 & 38 & 77 & 84 & 82 & 82 & 84 \\ \text { Range } & 18 & 19 & 15 & 28 & 29 & 71 & 77 & 74 & 79 & 78 \\ & 63 & 71 & 51 & 51 & 49 & 93 & 92 & 87 & 90 & 90\end{array}$

Group II $(\mathrm{N}=10)$

$\begin{array}{lrrrrrrrrr}\text { Average } & 22 & 23 & 30 & 34 & 82 & 84 & 87 & 83 \\ \text { Median } & 23 & 25 & 30 & 34 & 80 & 85 & 88 & 86 \\ \text { Range } & 7 & 7 & 21 & 22 & 68 & 74 & 74 & 62 \\ & 35 & 38 & 38 & 46 & 99 & 99 & 94 & 92\end{array}$

Group III $(N=13)$

$\begin{array}{lllllll}\text { Average } & 30 & 31 & 33 & 83 & 81 & 85 \\ \text { Median } & 33 & 33 & 36 & 83 & 82 & 86 \\ \text { Range } & 11 & 11 & 13 & 79 & 59 & 65 \\ & 41 & 48 & 48 & 100 & 93 & 98\end{array}$

"Grouping was based on length of participation I-5 yrs,., II-4 yrs., and III-3 yrs. ${ }^{b} Y_{1}, Y_{2}, Y_{3}, Y_{4}, Y_{5}$ designate consecutive years of project participation. 
represented. The smallest herd in the sample was in group II with only? cows in years one and two. Additionally, data on proportion of cows in milk show that out of those seven cows only 68 and 74 percent were in milk during years one and two respectively.

The data on cow numbers and proportion of cows in milk suggest that each group (I, II, and III) experienced positive growth in herd size as well as an increased proportion of the herds in milk. This would suggest, as will be seen later, that overall productivity increased. Figure II summarizes the dynamics of herd size changes during the first three years of component participation. The herd size categories: (a) 25 head or less; (b) 26 to 35 head; and (c) 36 head or more were arbitrarily chosen to observe the changes through time. The trend was toward larger herds. Fluctuation in the variables (cow number, proportion of cows in milk, and total productivity) during the time period covered were regarded, in part, as growth adjustments for the alignment of cow numbers with labor, equipment, and investment. As will be seen in the next section on investment, many of the farmers invested money in cows, milking facilities and equipment.

In the first year of component participation, 40 


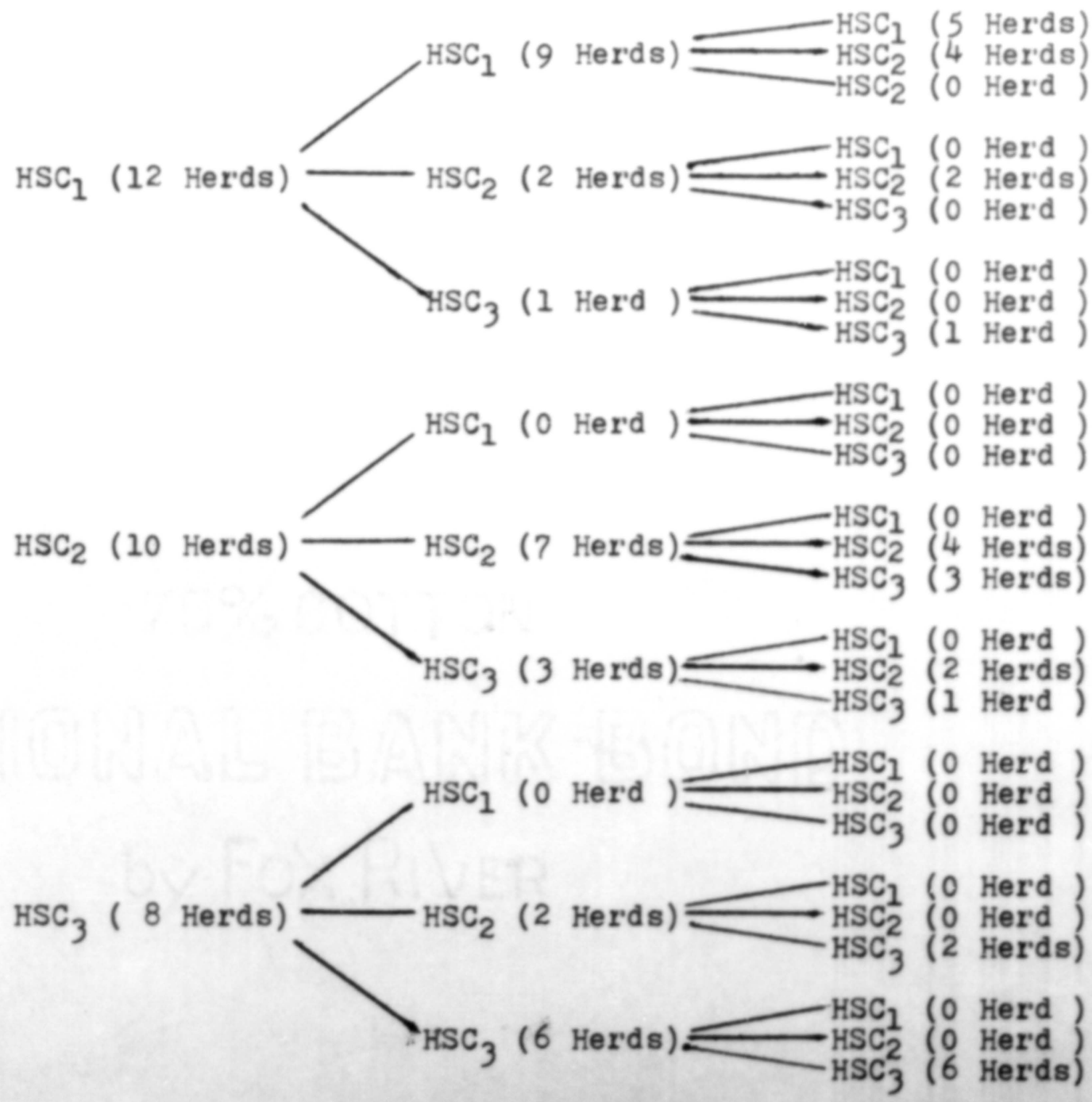

PIGURE II

Dynamics of herd size change over 3 years of component participation 
percent of the herds were recorded as comprised of 25

cows or less, with a median size of sixteen and one third. For the same period 33 percent of the herds comprised of from 26 to 35 cows and approximately 27 percent had herd sizes numbering 36 or more. The median sizes for the middle and upper size categories were 30 and 39 respectively. Data show that in the third year of component participation median cow numbers for each of the three herd size categories did not change tremendously. However, substantial change was realized respective to the percentage of the sample falling in each. Herds categorized in the largest size category ( 36 head or more) increased from one quarter to almost one half of the total sample number in the third year. Concomitantly, those herds categorized in the smallest size group (25 head and less) decreased from 40 percent to around 17 percent during the first three years of component participation. The change came about in a fashion such that smaller herds, initially categorized in the lower size group, contributed to the increased number in both the middle and upper size categories during the three year period.

Production: Volume And Value

Volume of production, having been designated as a 
feasible measure of herd size as well as herd performance, was observed to determine if there was substantial change over the three years of component participation. Data regarding daily and annual milk production for each of the 30 herds are presented in Table VIII. The data, as presented, provide only for comparing the daily and annual milk production in each year of component participation. Sixty-six percent of the herds realized increases in daily volume of production from year one to year two. Practional fluctuations in milking volume were felt to have been attributed to culling and replacement practices which were attempts at upgrading the quality of the herd. Many of the farmers were initially milking low producers which were detected by DHIA Sampler Testing. Subsequent to their detection low producers were replaced by younger stock which had initial low yield but were to bolster herd milk output in time.

Data regarding average total pounds of milk produced daily and annually by the three size groups and respective to years of component participation are presented in Table IX.

Average total pounds of milk produced daily and annually and the corresponding values included different situations for the three "size category groups." Group 


\section{TABLE VIII}

VOLUME OF PRODUCTION DAILY AND ANNUALLY BY HERD AND BY YEAR OF COMPONENT OPERATION

\begin{tabular}{|c|c|c|c|c|c|c|}
\hline \multirow{2}{*}{$\begin{array}{l}\text { Herd Identi- } \\
\text { fication }\end{array}$} & \multicolumn{3}{|c|}{ Production Daily } & \multicolumn{3}{|c|}{ Production Annually } \\
\hline & $\begin{array}{l}\text { Year I } \\
\text { (1bs) }\end{array}$ & $\begin{array}{c}\text { Year II } \\
(1 \mathrm{bs})\end{array}$ & $\begin{array}{l}\text { Year III } \\
(1 \mathrm{bs})\end{array}$ & $\begin{array}{l}\text { Year I } \\
\text { (1bs) }\end{array}$ & $\begin{array}{l}\text { Year II } \\
(1 \mathrm{bs})\end{array}$ & $\begin{array}{l}\text { Year III } \\
\text { (1bs) }\end{array}$ \\
\hline $\begin{array}{l}01-4(+++) \\
02-4(++*) \\
03-4(+++) \\
04-4(--+) \\
05-4(++*) \\
06-4(+*+) \\
07-4(--+) \\
08-4(--+) \\
09-4(-++) \\
10-4(--*) \\
11-5(---) \\
12-5(-++) \\
13-5(* * *) \\
14-5(--+) \\
15-5(+*+) \\
16-5(* * *) \\
17-5(* * *) \\
18-3(---) \\
19-3(+++) \\
20-3(* * *) \\
21-3(*+*) \\
22-3(---)\end{array}$ & $\begin{array}{r}493 \\
410 \\
349 \\
237 \\
643 \\
803 \\
603 \\
100 \\
539 \\
318 \\
288 \\
361 \\
897 \\
598 \\
686 \\
1118 \\
650 \\
436 \\
992 \\
720 \\
818 \\
403\end{array}$ & $\begin{array}{r}538 \\
840 \\
619 \\
257 \\
1,048 \\
722 \\
306 \\
96 \\
696 \\
327 \\
400 \\
499 \\
1,228 \\
544 \\
592 \\
1,285 \\
1,003 \\
510 \\
618 \\
862 \\
620 \\
462\end{array}$ & $\begin{array}{r}490 \\
1,282 \\
452 \\
518 \\
1,218 \\
775 \\
645 \\
199 \\
731 \\
866 \\
221 \\
592 \\
1,076 \\
901 \\
574 \\
1,185 \\
858 \\
383 \\
618 \\
967 \\
1,170 \\
502\end{array}$ & $\begin{array}{r}179,958 \\
149,644 \\
127,256 \\
86,392 \\
234,760 \\
293,189 \\
220,191 \\
36,677 \\
196,757 \\
116,171 \\
105,337 \\
131,778 \\
327,452 \\
218,232 \\
250,353 \\
407,908 \\
237,133 \\
159,066 \\
362,029 \\
262,841 \\
298,734 \\
147,270\end{array}$ & $\begin{array}{r}196,412 \\
306,870 \\
226,092 \\
93,900 \\
382,882 \\
263,691 \\
111,769 \\
35,266 \\
254,170 \\
119,462 \\
145,829 \\
182,287 \\
448,358 \\
198,786 \\
215,999 \\
469,165 \\
366,281 \\
186,232 \\
225,440 \\
314,635 \\
226,318 \\
168,958\end{array}$ & $\begin{array}{l}178,659 \\
467,907 \\
165,099 \\
181,166 \\
444,738 \\
282,983 \\
235,342 \\
72,859 \\
266,891 \\
316,076 \\
80,660 \\
215,988 \\
392,591 \\
328,886 \\
209,598 \\
432,436 \\
313,424 \\
139,910 \\
225,440 \\
353,103 \\
427,208 \\
183,410\end{array}$ \\
\hline
\end{tabular}


TABLE VIII (continued)

\begin{tabular}{|c|c|c|c|c|c|c|}
\hline \multirow{2}{*}{$\begin{array}{l}\text { Herd Identi- } \\
\text { fication }\end{array}$} & \multicolumn{3}{|c|}{ Production Daily } & \multicolumn{3}{|c|}{ Production Annually } \\
\hline & $\begin{array}{l}\text { Year I } \\
\text { (1bs) }\end{array}$ & $\begin{array}{l}\text { Year II } \\
\text { (1bs) }\end{array}$ & $\begin{array}{l}\text { Year III } \\
\text { (1bs) }\end{array}$ & $\begin{array}{l}\text { Year I } \\
\text { (1bs) }\end{array}$ & $\begin{array}{c}\text { Year II } \\
(1 \mathrm{bs})\end{array}$ & $\begin{array}{l}\text { Year III } \\
\text { (1bs) }\end{array}$ \\
\hline $\begin{array}{l}23-3(+* *) \\
24-3(*+*) \\
25-3(* * *) \\
26-3(* * *) \\
27-3(+* *) \\
28-3(---) \\
29-3(--+) \\
30-3(+++)\end{array}$ & $\begin{array}{l}425 \\
716 \\
956 \\
700 \\
714 \\
276 \\
314 \\
869\end{array}$ & $\begin{array}{r}1,084 \\
989 \\
1,509 \\
854 \\
1,322 \\
164 \\
76 \\
712\end{array}$ & $\begin{array}{r}888 \\
908 \\
1,432 \\
802 \\
570 \\
502 \\
689 \\
970\end{array}$ & $\begin{array}{l}155,290 \\
261,573 \\
348,866 \\
255,624 \\
260 ; 763 \\
100,656 \\
114,919 \\
317,254\end{array}$ & $\begin{array}{r}395,934 \\
361,034 \\
550,785 \\
311,884 \\
482,599 \\
60,147 \\
27,922 \\
260,125\end{array}$ & $\begin{array}{l}324,280 \\
331,479 \\
522,948 \\
292,922 \\
570,405 \\
183,216 \\
251,557 \\
354,038\end{array}$ \\
\hline
\end{tabular}

(-) denotes size category one classification, 25 head or less.

(+) denotes size category two classification, 26-35 head.

*) denotes size category three classification, 36 head and more.

$(a, b, c)$ the first second and third code entries designate year of participation. 
TABLE IX
AVERAGE TOTAL POUNDS OF MILK PRODUCED DAILY AND ANNUALLY BY HERD SIZE CATEGORY AND BY YEAR OF COMPONENT PARTICIPATION

\begin{tabular}{|c|c|c|c|c|c|}
\hline \multirow{2}{*}{\multicolumn{2}{|c|}{$\begin{array}{l}\text { Size Category } \\
\text { and Stages }\end{array}$}} & \multicolumn{4}{|c|}{ Milk Produced } \\
\hline & & $\begin{array}{l}\text { Daily } \\
\text { (1bs) }\end{array}$ & $\begin{array}{c}\text { Value } \\
\text { (\$ Daily) }\end{array}$ & $\begin{array}{l}\text { Annually } \\
\text { (1bs) }\end{array}$ & $\begin{array}{l}\text { Value } \\
\text { (\$ Annually) }\end{array}$ \\
\hline \multicolumn{6}{|c|}{$\begin{array}{l}\text { Twenty-Five Head } \\
\text { or Less }\end{array}$} \\
\hline $\begin{array}{l}\text { Year I } \\
\text { Year II } \\
\text { Year III }\end{array}$ & $\begin{array}{l}\left(\begin{array}{l}\mathrm{N}=12 \\
\mathrm{~N}=7\end{array}\right) \\
\mathrm{N}=5\end{array}$ & $\begin{array}{l}373 \\
314 \\
260\end{array}$ & $\begin{array}{l}15.93 \\
13.62 \\
15.93\end{array}$ & $\begin{array}{l}149,061 \\
114,827 \\
132,011\end{array}$ & $\begin{array}{l}5,814 \\
4,973 \\
7,139\end{array}$ \\
\hline \multicolumn{6}{|c|}{$\begin{array}{l}\text { Twenty-Six to } \\
\text { Thirty-Five Head }\end{array}$} \\
\hline $\begin{array}{l}\text { Year I } \\
\text { Year II } \\
\text { Year III }\end{array}$ & $\begin{array}{l}\left(\begin{array}{l}\mathrm{N}=10 \\
\mathrm{~N}=11 \\
\mathrm{~N}=12\end{array}\right) \\
\text {. }\end{array}$ & $\begin{array}{l}638 \\
718 \\
663\end{array}$ & $\begin{array}{l}30.51 \\
32.76 \\
30.21\end{array}$ & $\begin{array}{l}233,002 \\
262,163 \\
235,609\end{array}$ & $\begin{array}{r}11,157 \\
11,962 \\
9,391\end{array}$ \\
\hline \multicolumn{6}{|c|}{$\begin{array}{l}\text { Thirty-Six Head } \\
\text { and More }\end{array}$} \\
\hline $\begin{array}{l}\text { Year I } \\
\text { Year II } \\
\text { Year III }\end{array}$ & $\begin{array}{l}\left(\begin{array}{l}\mathrm{N}=8) \\
\mathrm{N}=10 \\
\mathrm{~N}=13\end{array}\right) \\
\text { (1) }\end{array}$ & $\begin{array}{r}822 \\
1026 \\
1093\end{array}$ & $\begin{array}{l}36.81 \\
50.77 \\
53.74\end{array}$ & $\begin{array}{l}300,016 \\
381,933 \\
375,901\end{array}$ & $\begin{array}{l}13,436 \\
18: 532 \\
18,364\end{array}$ \\
\hline
\end{tabular}


"one" ( $<25$ cows) was characterized by continually declining average total pounds of milk produced daily. Between years I and II, and II and III average total pounds of milk produced daily declined by -16 and -17 percent respectively. Value of yearly production for group one showed a different trend. While it decreased by -15 percent between years I and II, it increased by 17 percent between years 2 and 3 . These results suggest that the price received per hundred pounds of milk, by group one, increased substantially between the latter two years. The number of herds retaining size category one identity over the three years changed markedly. 01 the 12 herds classified in category one during year I, only 42 percent were so-categorized in year III. Obviously, the majority of herds increased in size and moved to a higher size classification. Moreover, it is suspected that the more productive herds in the group moved up, hence lower producers remained in group one and accounted for declining average total pounds of milk produced. Value of annual production went from $\$ 5,814$ to $\$ 7.139$ dollars, a change of 23 percent for group one.

Average total pounds of milk produced daily and annually by size category "two" (26-35 cows) was characterized by increase between years 1 and 2, and decrease between years II and III. Values of production reflected 
the same trend. While the number of herds increased by 10 percent for both periods (years I to II and years II to III) respectively, value of annual production showed changes of 7 percent and 21 percent respectively for the two periods.

Size category "three" was characterized by increases in: (a) herd composition, (b) average total pounds of milk produced daily and annually, and (c) corresponding values of production. The number of herds was up by 27 percent between years I and III. Average total pounds of milk produced daily and the value of daily production increased by 33 and 46 percent, respectively, between years I and III. The ratio of increase in daily production to the increase in value suggests that prices were swiftly increasing. Though there was divergence in the rates of change in production and value of production among the three groups, the increasing value of product shared by all size categories suggest increasing returns to labor and capital.

\section{Feed $\underline{\text { Costs }}$}

Table $X$ contains data regarding daily feed cost per cow and per hundred pounds of milk produced, by respective herd size categories. Median feed cost per day per cow was similar for the three year period for each herd size category. Feed cost per hundred pounds of milk appear to 
TABLE $X$

AVERAGE, MEDIAN, AND RANGE VALUES OF DAILY FEBD COST PER COW, AND PER HUNDRED POUNDS OF MILK PRODUCED BY SIZE CATEGORY IN YEARS I, II, III OF COMPONENT OPERATION

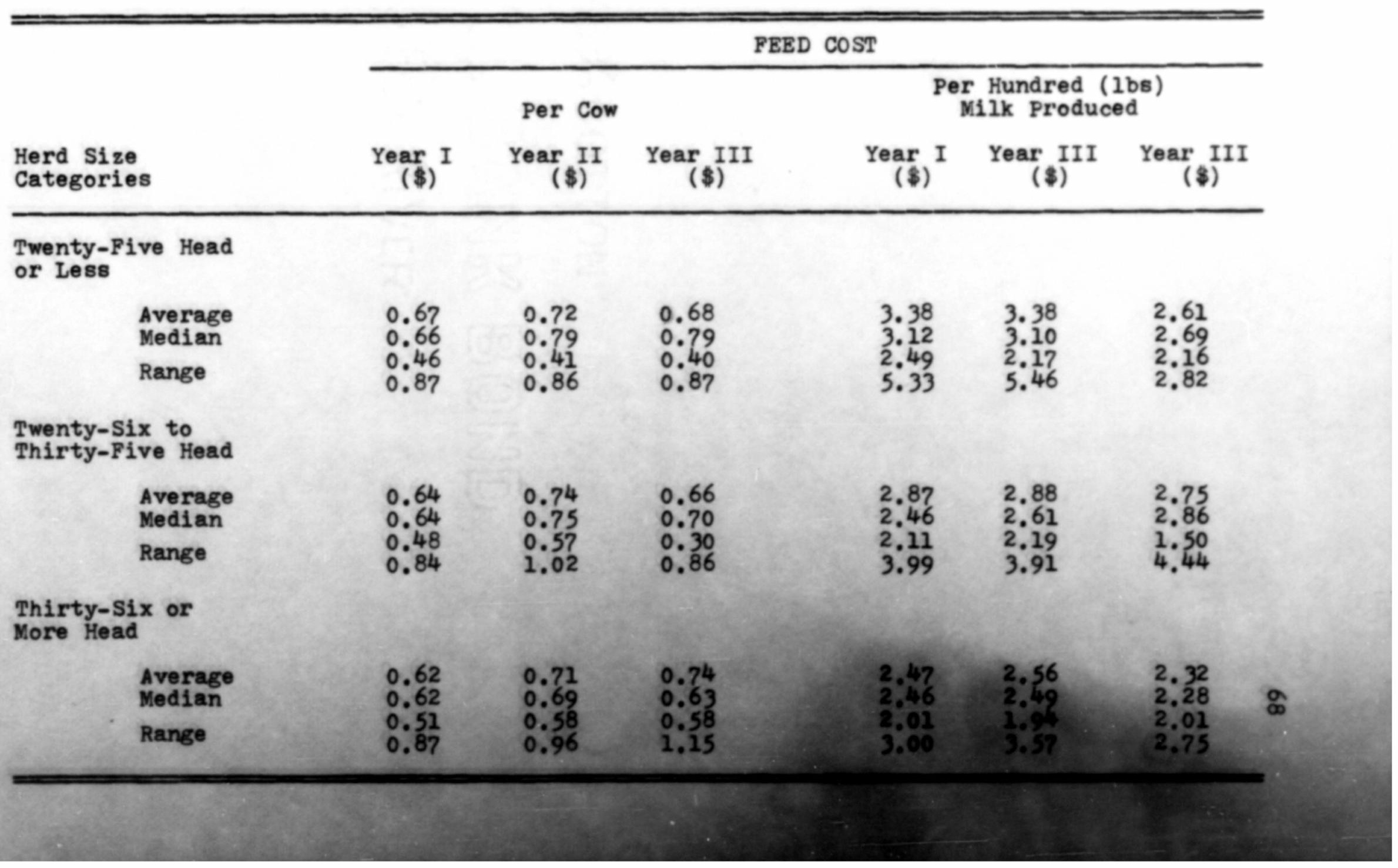


reflect some economies of size.

Although low income farmers are generally characterized as inefficient, it appeared that dairymen in the sample achieved a higher level of feed efficiency. Feed cost per hundred weight declined substantially between the first and third years of component participation.

Concomitant to declining feed costs, the smaller and larger herd size categories realized increased values of daily product per cow. (Table XI) This was interpreted as positive indication of increased income over feed costs, and higher average incomes for participating dairymen. Again, milk prices had some effect.

Data presented regarding variables indicative of size suggest that the herds tended to pursue a pattern of overall growth. Since, concomitant to increase in cow number, farmers on the average realized increased production, increased value of product, and increased feed efficiency, it appeared that the component's objective regarding "alignment of cow numberswith resources" was realized.

\section{INVESTMENT}

The mail questionnaire aided in securing data regarding investment over the five year period (1966-70). $A$. questionnaire was mailed to seventy-five of the profect 
TABLE XI

PER-DAY VALUE OF PRODUCTION PER COW AS RECORDED FOR THE THIRTY HERDS INCLUDED IN THE SAMPLE, BY SIZE CATEGORY AND YEAR OF COMPONENT PARTICIPATION

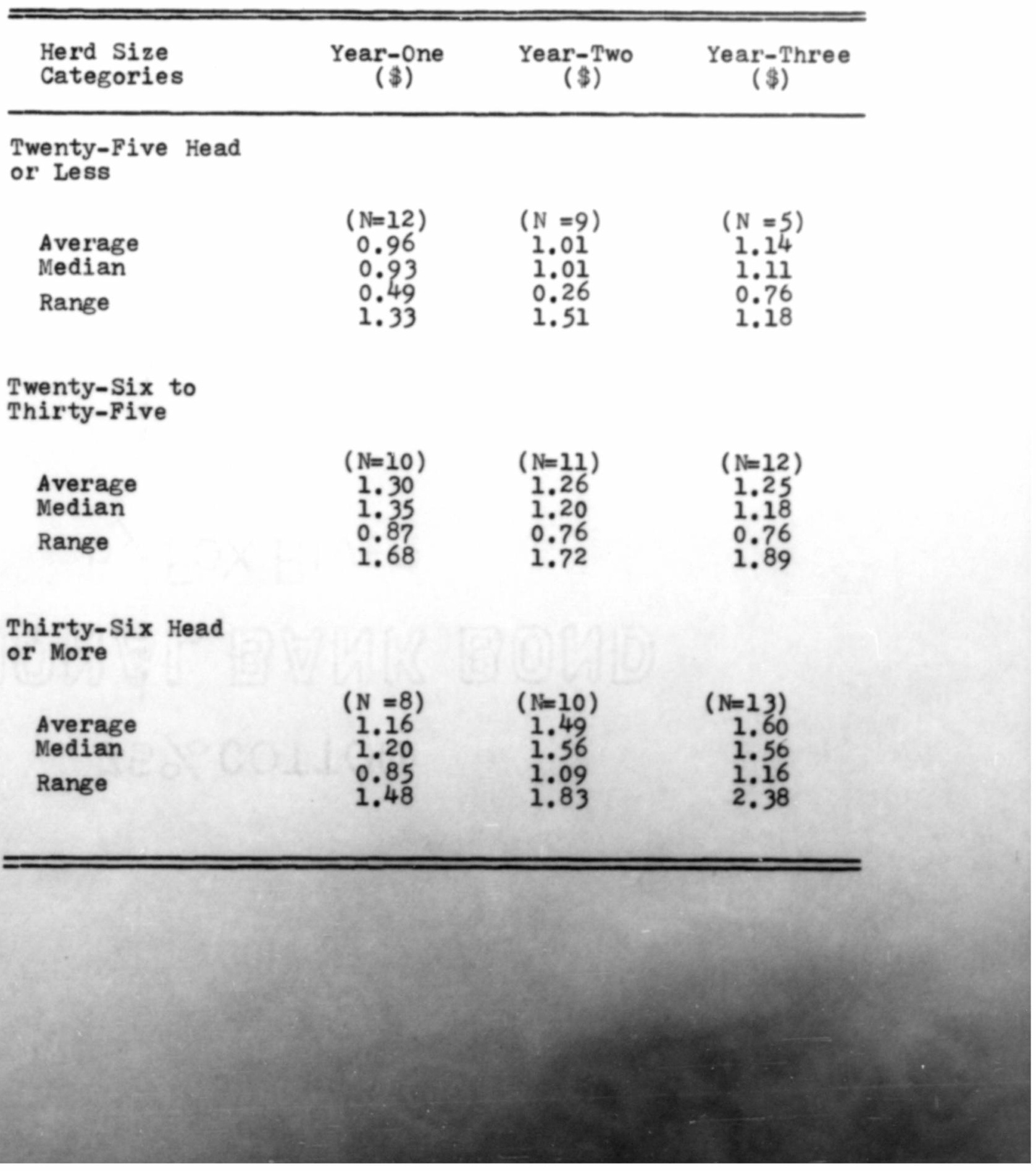


participants. Thirty-eight responded. Data were acquired on: (a) magnitude of investment, (b) use of investment, (c) sources of funds, and (d) terms of repayment. The responding farmers were divided into categories based upon the length of participation in the Ozark Dairy Management project. The categories were: (1) one to-two years, (2) three years, and (3) four-to five years.

\section{Investment Volume}

Table XII contains data on the volume of investment. Farmers who participated in the dairy program for one-totwo years were reported to have invested $\$ 33,832$ on the average per farmer, or $\$ 6,766$ on the average per year, between 1966 and 1970. The group of farmers represented by a participation span of three years invested $\$ 34,657$ on the average per farmer, and $\$ 6,931$ per farmer per year. The farmers who participated 4-5 years had invested $\$ 23.583$ per farmer; and $\$ 4,716$ dollars per farmer per year. The investment figures listed above typify only those 38 respondents who returned the questionnaire. Dairymen who participated three years or less made investments substantially greater than those of four or five year participation. These results may suggest a relationship between length of participation and financial position. The farmers of shorter participation duration and larger 
TABLE XII

INVESTMENT DURING THE PERIOD (1966-1970) BY THE LOW INCOME DAIRY FARMERS BY LENGTH OF PARTICIPATION IN THE COMPONENT

\begin{tabular}{|c|c|c|c|}
\hline $\begin{array}{l}\text { Groups By } \\
\text { Years of } \\
\text { Participation }\end{array}$ & $\begin{array}{l}\text { Total } \\
\text { Group } \\
\text { Investment }\end{array}$ & $\begin{array}{l}\text { Average } \\
\text { Total } \\
\text { Investment } \\
\text { (Farmer) }\end{array}$ & $\begin{array}{c}\text { Average } \\
\text { Total } \\
\text { Investment } \\
\text { (Farmer/Year) }\end{array}$ \\
\hline & (\$) & (3) & $(\$)$ \\
\hline $\begin{array}{l}\text { One to Two } \\
\text { Years } \\
(\mathrm{N}=24)\end{array}$ & 811,991 & 33,832 & 6.766 \\
\hline $\begin{array}{l}\text { Three Years } \\
\qquad(N=8)\end{array}$ & 277,256 & 34,657 & 6.931 \\
\hline $\begin{array}{l}\text { Pour to Five } \\
\text { Years } \\
(N=6)\end{array}$ & 141,500 & 23.583 & 4.716 \\
\hline
\end{tabular}


investment volume may have been better off financially, adjudged lower risk by lenders, or more capable in managing investment.

\section{Use of Investment}

Table XIII shows proportion of investment utilized in four asset types. Those farmers who participated for one to two years invested primarily in land and expansion of the milking herd; 54 and 20 percent, respectively. The purchase of land seemed to have been a dominant use of investment funds by all three groups of farmers.

\section{Credit Sources}

The primary sources of credit, as reported by the respondents, were Production Credit Associations, Farmers Home Administration, Banks, Local Merchants, Loan Associations and private individuals or family members. Data regarding sources of credit and proportionate usage are presented in Table XIV. Bank loans were utilized more heavily by participants in the 1-2 year participation category while group II patronized P.C.A. most heavily.

Local banks were reportedly used more extensively than any other source. of the total loans made, 40 percent were secured from banks. Other sources showing more intense use were P.H.A., P.C.A., and relatives. The proportion of total loans secured from each of these 
TABLE XIII

PROPORTIONS OF GROUP INVESTMENT USED IN VARIOUS USE CATEGORIES

\begin{tabular}{|c|c|c|c|c|c|}
\hline \multirow[b]{2}{*}{$\begin{array}{l}\text { Groups By Years } \\
\text { In Project }\end{array}$} & \multicolumn{5}{|c|}{ Asset Types and Proportions Invested (In Dollars) } \\
\hline & $\begin{array}{l}\text { Facilities and } \\
\text { Bquipment } \\
(\%)\end{array}$ & $\begin{array}{c}\text { Herd } \\
\text { Expansion } \\
(\%)\end{array}$ & $\underset{(\%)}{\operatorname{Land}}$ & $\underset{(\%)}{\operatorname{Machinery}}$ & Totals \\
\hline $\begin{array}{l}\text { one to Two Years } \\
(\mathrm{N}=24)\end{array}$ & 12.12 & 20.10 & 54.24 & 13.45 & 100.00 \\
\hline $\begin{array}{l}\text { Three Years } \\
\qquad(N=8)\end{array}$ & 12.18 & 22.48 & 39.56 & 25.78 & 100.00 \\
\hline $\begin{array}{l}\text { Pour to Pive Years } \\
(N=6)\end{array}$ & 11.95 & 34.27 & 33.78 & 20.00 & 100.00 \\
\hline
\end{tabular}


TABLE XIV

CREDIT SOURCES AND PROPORTION OF LOANS SECURED FROM BACH SOURCE DURING 1966-1970

\begin{tabular}{|c|c|c|c|c|c|c|c|}
\hline \multirow{2}{*}{$\begin{array}{l}\text { Groups By Years } \\
\text { In Project }\end{array}$} & \multirow{2}{*}{$\begin{array}{l}\text { Total } \\
\text { Loans } \\
\text { Made By } \\
\text { Groups }\end{array}$} & \multicolumn{6}{|c|}{ Credit Sources } \\
\hline & & P.C.A. & P.H.A. & Bank & $\begin{array}{l}\text { Local } \\
\text { Merchant }\end{array}$ & $\begin{array}{l}\text { Loan } \\
\text { Assn. }\end{array}$ & $\begin{array}{c}\text { Other } \\
\text { (Relatives) }\end{array}$ \\
\hline $\begin{array}{l}\text { One to Two Years } \\
(\mathrm{N}=24)\end{array}$ & 48 & $33.33^{\mathrm{a}}$ & 66.66 & 72.00 & 100.00 & 75.00 & 62.50 \\
\hline $\begin{array}{l}\text { Three Years } \\
\qquad(N=8)\end{array}$ & 16 & 55.55 & 20.01 & 14.00 & 0.00 & 25.00 & 37.50 \\
\hline \multirow[t]{2}{*}{$\begin{array}{l}\text { Four to Five } \\
\qquad(\mathrm{N}=6)\end{array}$} & 8 & 11.12 & 13.33 & 14.00 & 0.00 & 0.00 & 0.00 \\
\hline & & 100.00 & 100.00 & 100.00 & 100.00 & 100.00 & 100.00 \\
\hline Total Loans & 72 & 9 & 15 & 29 & 7 & 4 & 8 \\
\hline Percent Total Loans & & 12.50 & 20.83 & 40.27 & 9.72 & 5.55 & 11.13 \\
\hline
\end{tabular}

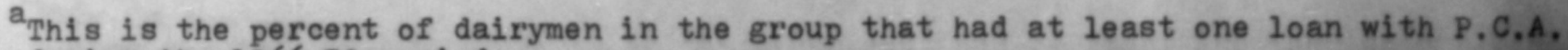
during the $1966-70$ period. 
respective sources were 21,13, and 11 percent.

Borrowing by farmers who participated in the project for four to five years was limited to P.C.A., P.H.A., and bank loans. There was not much divergence respective to the intensity with which the four to five year participants utilized the three sources.

Borrowing by the one to two year project participants was not limited from either source. Group I farmers secured loans from all sources. Results suggests that group I participants were either well aware of some advantages in securing and using credit to enhance higher incomes or they had no difficulty in convincing lenders of their ability to repay.

\section{Repayment Terms of Loans}

The repayment terms of the loans were grouped into four categories: (a) 1-12 months, (b) 13-16 months, (c) 1736 months, and (d) 36 months and greater. Data in Table XV shows the percentage of total loans falling in each repayment category as well as the proportion of loans by each group of farmers that fall within each such repayment category. Also shown is the proportion of each repayment category loans ascribed to each group. Generally, it was observed that the low income dairy farmers who responded were able to secure some 
REPAYMENT TERMS OF LOANS BY FARMER GROUPS BASED ON LENGTH OF PARTICIPATION AND BY LENGTH OP REPAYMENT PERIODS

\begin{tabular}{|c|c|c|c|c|c|c|c|}
\hline \multirow{3}{*}{$\begin{array}{l}\text { Length of } \\
\text { Loans }\end{array}$} & \multirow{3}{*}{$\begin{array}{c}\% \\
\text { Total } \\
\text { Loans }\end{array}$} & \multicolumn{6}{|c|}{ Groups And Proportions } \\
\hline & & \multicolumn{2}{|c|}{$\begin{array}{l}\text { one to Two Years } \\
\qquad(\mathrm{N}=24)\end{array}$} & \multicolumn{2}{|c|}{$\begin{array}{c}\text { Three Years } \\
(\mathrm{N}=8)\end{array}$} & \multicolumn{2}{|c|}{ Four to $\begin{array}{l}\text { Five } \\
(N=6)\end{array}$} \\
\hline & & $\begin{array}{l}\text { Group } \\
(\%)\end{array}$ & $\begin{array}{c}\text { Category } \\
(\%)\end{array}$ & $\begin{array}{l}\text { Group } \\
(\%)\end{array}$ & $\begin{array}{c}\text { Category } \\
(\%)\end{array}$ & $\begin{array}{l}\text { Group } \\
(\%)\end{array}$ & $\begin{array}{c}\text { Category } \\
(\%)\end{array}$ \\
\hline 1-12 Mos. & 20.83 & $20 \cdot 32$ & 65.00 & 0.00 & 0.00 & 43.75 & 35.00 \\
\hline $13-16$ Mos. & 9.37 & 14.06 & 100.00 & 0.00 & 0.00 & 0.00 & 0.00 \\
\hline 17-36 Mos. & 18.75 & 20.32 & 12.22 & 6.25 & 5.55 & 25.00 & 22.22 \\
\hline $\begin{array}{l}36 \text { Mos, and } \\
\text { Longer }\end{array}$ & 44.89 & 40.62 & 60.68 & 87.50 & 33.66 & 18.75 & 5.66 \\
\hline other & 6.25 & 4.68 & 50.00 & 6.25 & 16.66 & 12.50 & 33.33 \\
\hline Totals & 100.00 & 100.00 & & 100.00 & & 100.00 & \\
\hline
\end{tabular}


amount of long term financing. Forty-four percent of total loans secured by the respondents were for 36 months or longer. These were probably land or machinery loans. The one to two year participants were the heavier users of short term credit. Dairy farmer's who were in the project four years and longer also used substantial short term credit.

All three groups of farmers secured loans of no definitely structured repayment period. Usually, those loans were secured from fathers or some other family member or relative.

IV. PARTICIPANT ATTITUDES REGARDING THE COMPONENT

The success of any group endeavor is determined in part by the effort, attitudes, and enthusiasm exerted by that group. In this section data are presented with regard to participant attitudes towards and opinions about the Ozark Dairy Management Component.

\section{Change in Managerial Ability}

Data reflecting participants attitudes regarding subsequent ability to do a good job at dairying are presented in Table XVI. In the questionnaire an item was included which requested participant response regarding perceived improvement in his dairying ability. Reeponses 
TABLE XVI

PARTICIPANT OPINIONS REGARDING RESULTANT ABILITY

TO DO A GOOD JOB AT DAIRYING

\begin{tabular}{|c|c|c|c|c|c|}
\hline \multirow[b]{2}{*}{$\begin{array}{l}\text { Groups By } \\
\text { Length of } \\
\text { Participation }\end{array}$} & \multicolumn{5}{|c|}{ Degree of Improvement } \\
\hline & $\begin{array}{l}\text { Improved } \\
\text { Tremendously } \\
(\%)\end{array}$ & $\begin{array}{l}\text { Improved } \\
\text { Some } \\
(\%)\end{array}$ & $\begin{array}{l}\text { No } \\
\text { Inprovement } \\
(\%)\end{array}$ & $\begin{array}{l}\text { No } \\
\text { Response } \\
(\%)\end{array}$ & Totals \\
\hline $\begin{array}{l}\text { One to Two year } \\
\text { Participants } \\
\qquad(N=24)\end{array}$ & 28.58 & 22.42 & 27.58 & 21.42 & 100.00 \\
\hline $\begin{array}{l}\text { Three Year } \\
\text { Participants } \\
\qquad(N=8)\end{array}$ & $37 \cdot 50$ & 50.00 & 0.00 & 12.50 & 100.00 \\
\hline $\begin{array}{l}\text { Four to Five Year } \\
\text { Participants } \\
(\mathrm{N}=6)\end{array}$ & 16.67 & 66.67 & 16.66 & 0.00 & 100.00 \\
\hline $\begin{array}{l}\text { Summation } \\
\text { All Groups }\end{array}$ & 23.68 & 47.37 & 15.79 & 13.16 & 100.00 \\
\hline
\end{tabular}


revealed that the majority of the farmers felt that their abilities had improved. Approximately sixteen percent indicated that their ability had not improved. Another 13 percent did not care to comment. Since perceived initial ability possessed by the respondents was unknown, degree of improvement was not used to imply project noneffectiveness.

\section{Attitudes Toward Dairy Aides}

Dairy aides worked directly with the participants. The use of aides is based upon the theory that participants respond "best" to their peers. These aides were selected from among area dairy farmers and trained to assist the partici pants.

Because aides have been strategic to the project, effort was made to determine participant attitudes toward assistance received from dairy aides. The majority of farmers who responded felt that the assistance provided by the aides was satisfactory or completely satisfactory. (Table XVII)

The largest reported percentage of farmers who indicated that dairy aide assistance was unsatisfactory came from the one to two year group. Ascertaining reasons for indicating unsatisfactory assistance (fram participants who so reported) likely could have provided further insight. However, it was not attemptod. 
TABLE XVII

OPINIONS REGARDING ASSISTANCE RECEIVED FROM AIDES WITH THE

OZARK DAIRY MANAGEMENT COMPONENT

\begin{tabular}{|c|c|c|c|c|c|}
\hline $\begin{array}{l}\text { Groups by Length } \\
\text { of Participation }\end{array}$ & $\begin{array}{l}\text { Completely } \\
\text { Satisfactory }\end{array}$ & Satisfactory & Unsatisfactory & No Reply & Totals \\
\hline $\begin{array}{l}\text { One to Two Year } \\
\text { Participants } \\
\qquad(\%=24)\end{array}$ & 20.83 & 29.17 & 20.83 & 29.17 & 100.00 \\
\hline $\begin{array}{l}\text { Three Year } \\
\text { Participants } \\
\qquad(N=8)\end{array}$ & 37.50 & 50.00 & 12.50 & 0.00 & 100.00 \\
\hline $\begin{array}{l}\text { Four to Five Year } \\
\text { Participants } \\
(N=6)\end{array}$ & 33.33 & 50.00 & 16.67 & 0.00 & 100.00 \\
\hline Summation Groups & 26.32 & 36.84 & 18.42 & 18.42 & 100.00 \\
\hline
\end{tabular}




\section{Participation In Educational Activities}

The degree to which farmers were effectively assisted by the project probably hinged upon the degree to which they were motivated. One idea is that endogenous motivation is most crucial to the process of total motivation. One aspect of the component was to conduct meetings and farm tours for providing instruction and motivation wherein the low income farmers would be inspired to higher levels of management. Table XVIII provides data regarding frequency of meeting and tour attendance. Large proportions of the dairy farmers indicated that they attended none of the meetings or tours sponsored by the component project. Dairymen who had participated less than two years comprised 63 percent of the total sample group, yet they were the poorest attenders at meeting and tours.

It was speculated that the degree to which participants cited their opinions regarding the component and the degree to which the component was able to provide worthwhile assistance was related to the extent of wholehearted participant involvement in the component. 
TABLE XVIII

ATTENDANCE OF MEETINGS AND FARM TOURS BY THE LOW INCOME DAIRY FARMER PARTICIPANTS

\begin{tabular}{llllll}
\hline \hline & \multicolumn{5}{c}{ Rate of Attendence } \\
\cline { 2 - 6 } Participation & All & Some & None & No Reply & Total \\
\hline $\begin{array}{l}\text { One to Two } \\
\text { Years } \\
(\text { N=24) }\end{array}$ & 4.17 & 41.67 & 45.83 & 8.33 & 100.00 \\
$\begin{array}{l}\text { Three Years } \\
\quad(N=8)\end{array}$ & 12.50 & 37.50 & 50.00 & 0.00 & 100.00 \\
$\begin{array}{l}\text { Four to Five } \\
\text { Years } \\
(\text { N=6) }\end{array}$ & 16.67 & 50.00 & 33.33 & 0.00 & 100.00 \\
\hline $\begin{array}{l}\text { Summation } \\
\text { All Groups }\end{array}$ & 7.89 & 42.11 & 44.74 & 5.26 & 100.00 \\
\hline \hline
\end{tabular}




\section{INVESTMENT FEASIBILITY ANALYSIS}

\section{IDENTIFICATION OF INVESTMENT SPENDING}

As indicated in chapter four, the low income dairy farmers made considerable use of borrowed capital over the five years in which the Ozark Dairy Management Component was operative. The investment was made in asset types ranging from dairy animals to land. The respondents to the mail questionnaire $(N=38)$ invested approximately $\$ 1,230,747$ over the five year period 1966-1970. The averages invested per farmer over "the five years" and "per year" were $\$ 32,388$ and $\$ 6,478$ respectively. Public spending in the project over the first three years of operation was approximately $\$ 123,098$ dollars. Average public investments, per annum, in the project and per farmer were $\$ 41,032$ and $\$ 341$ dollars respectively.

Concomitant to the reported use of investment over the period of component operation, the sampled herds realized increases in: (a) production, (b) number of cows in milking herd, (c) median value of production, and (d) income over feed cost per cow.

During the first three years of component participation average total pounds of milk produced annually per 
herd increased by 30 percent. Average annual base production per herd was 194.026 pounds, while in the third year annual production per herd rose to 247,840 pounds. The average increase in herd size over base was 39 percent. Value of product on a daily basis increased by 20 percent. Median income over feed cost per cow and per herd increased by 70 and 79 percent respectively.

\section{INTERNAL RATE OF RETURN}

The internal rate of return was chosen as a means of measuring economic returns. The IRR is the rate which equates the discounted present value of future marginal yields from an investment to the investment cost. The IRR method of evaluating investments is a useful alternative to the Benefit Cost Analysis because they both suggest similar results.

The IRR was chosen over the $B / C$ analysis because it required a minimum of assumptions and judgements. Moreover, it did not require the specification of a discount rate, which has often been an inherent point of error in benefitcost analysis. That the IRR reflects percent of return makes it useful to businessmen and legislators.

$$
\text { In calculating the IRR for the low income dairy }
$$

component two sets of data were required, (a) a schedule of investments and (b) the schedule of not benofits over 
the specified period. Assumptions about future conditions had to be made.

Schedule of Investment

Private investment for the average farmer over the initial five year period (1966-1970) was assumed to have been made at a rate of $\$ 6,478$ in each year. In the remainder of the analysis period (1971-1975) it was assumed that no further private investments were made. Public investment, on the average, per farmer was calculated as $\$ 341$ per year. Because of rapid turnover in participants the average farmer received project assistance for only three years. Thus the assumed flow of public investment per farmer covered a three year span, when included in the schedule of total capital investment. The schedule of total investment (both public and private) was $\$ 6,819$ per annum for years one, two, and three, and $\$ 6,478$ per annum for years four and five. Interpretation of investment flow can be derived from Tables XIX through XXII.

\section{Schedule of Net Benefits}

Benefits from public and private investment programs can be broken down into two groups, primary and secondary. Primary or tangible benefits are the value of the product or services directly resulting from the enterprise. Secondary benefits are the values added over and above the 
TABLE XIX

INTERNAL RATE OF RETURN ON INVESTMENT AND IMPROVED MANAGEMENT

FOR A REPRESENTATIVE DAIRY FARM

IN THE OZARK DAIRY PROGRAM;

CASE I: NO IMPROVEMENT IN PRODUCTIVITY BEYOND YEAR 5

ARNUAL REIURN UN CAPITAL 12.24 PERCEN

\begin{tabular}{|c|c|c|c|c|c|c|c|c|c|c|c|}
\hline \multirow{2}{*}{\multicolumn{2}{|c|}{ YEAR }} & \multirow[b]{2}{*}{ FACILITIES } & NI 1 & 3 & 1 & \multirow{2}{*}{ 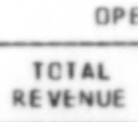 } & IING 1 & 1 & \multirow{2}{*}{$\begin{array}{l}\text { PRESENT } \\
\text { VALUE } \\
\text { FACTOR }\end{array}$} & PRESENT & VALUE \\
\hline & & & \multicolumn{2}{|c|}{$\begin{array}{l}\text { WORK ING } \\
\text { CAP ITAL }\end{array}$} & TOTAL & & $\begin{array}{l}\text { OPERATING } \\
\text { EXPENSES ** }\end{array}$ & $\begin{array}{c}\text { NE T } \\
\text { RE VE NUE }\end{array}$ & & I NVESTMENT & $\begin{array}{c}\text { NE T } \\
\text { REVENUE }\end{array}$ \\
\hline 0 & 1903 & 0. & & 0. & 0. & 0. & 0. & 0. & 1.0000 & 0. & 0. \\
\hline 1 & 1960 & 6819. & & 0. & 6819. & 0. & 0. & 0. & 0.8909 & 6075 . & 0. \\
\hline 2 & 1967 & 6819. & & 0. & 6819. & 813. & 0. & 813. & 0.7938 & 5413. & 645. \\
\hline 3 & 1968 & 6819. & & 0. & 6819. & 2926. & 0. & 2926. & 0.7072 & 4822. & 2069. \\
\hline 4 & 1969 & 6478 . & & 0. & 6478 . & 3888. & 0. & 3888. & 0.6301 & 4082. & 2450 . \\
\hline s & 1970 & 6478. & & 0. & 6478 . & 6548. & 0. & 6348. & 0.5614 & 3636. & 3676 . \\
\hline 6 & 1971 & 0. & & 0. & o. & 6548. & 0. & 6548 . & 0.5001 & 0. & 3275. \\
\hline 7 & 1912 & 0. & & 0. & 0. & 6548. & 0. & 6548. & 0.4456 & 0. & 2918. \\
\hline 8 & $1 \geqslant 73$ & 0. & & 0. & 0. & 6548 . & o. & 6548. & 0.3970 & 0. & 2600 . \\
\hline \multirow{3}{*}{10} & 1974 & 0. & & 0. & 0. & 6548. & 0. & 6548 . & 0.3537 & 0. & 2316. \\
\hline & 1975 & -6400 . & & 0. & $-64 \mathrm{co}$ & 6548. & 0. & 6548. & 0.3151 & -2017 & 2063. \\
\hline & TOTAL & 27013. & & 0. & 27013. & 46915 . & 0. & 46915. & & 22012 . & 22012. \\
\hline
\end{tabular}

\begin{tabular}{c} 
INIEREST \\
PER CENI \\
\hline 5.00 \\
10.00 \\
15.00 \\
20.00 \\
25.00 \\
30.00
\end{tabular}

BENEFIT/COST

PRESENT VALUE IN MEYENUE oullar

BALANGE

1.35
1.09
0.91
0.77
0.66
0.58

33807.

25046.

8761.

25004.22937 .2057$.

$18930.220912 . \quad-1982$.

14634. 19058. 19424.

11527.017400 .07873$.

$30.00-0.58$

15933.

**EXCLUDIING DEPRECIATION, INTEREST, aNd INCOME taX 
TABLE XX

INTERNAL RATE OF RETURN ON INVESTMENT AND IMPROVED MANAGEMENT

FOR A REPRESENTATIVE DAIRY FARM

IN THE OZARK DAIRY PROGRAM:

CASE II: NET REVENUE INCREASING AT 20 PERCENT PER ANNUM

AMNUAL RETURN GN CAPITAL 27.88 PERCENT

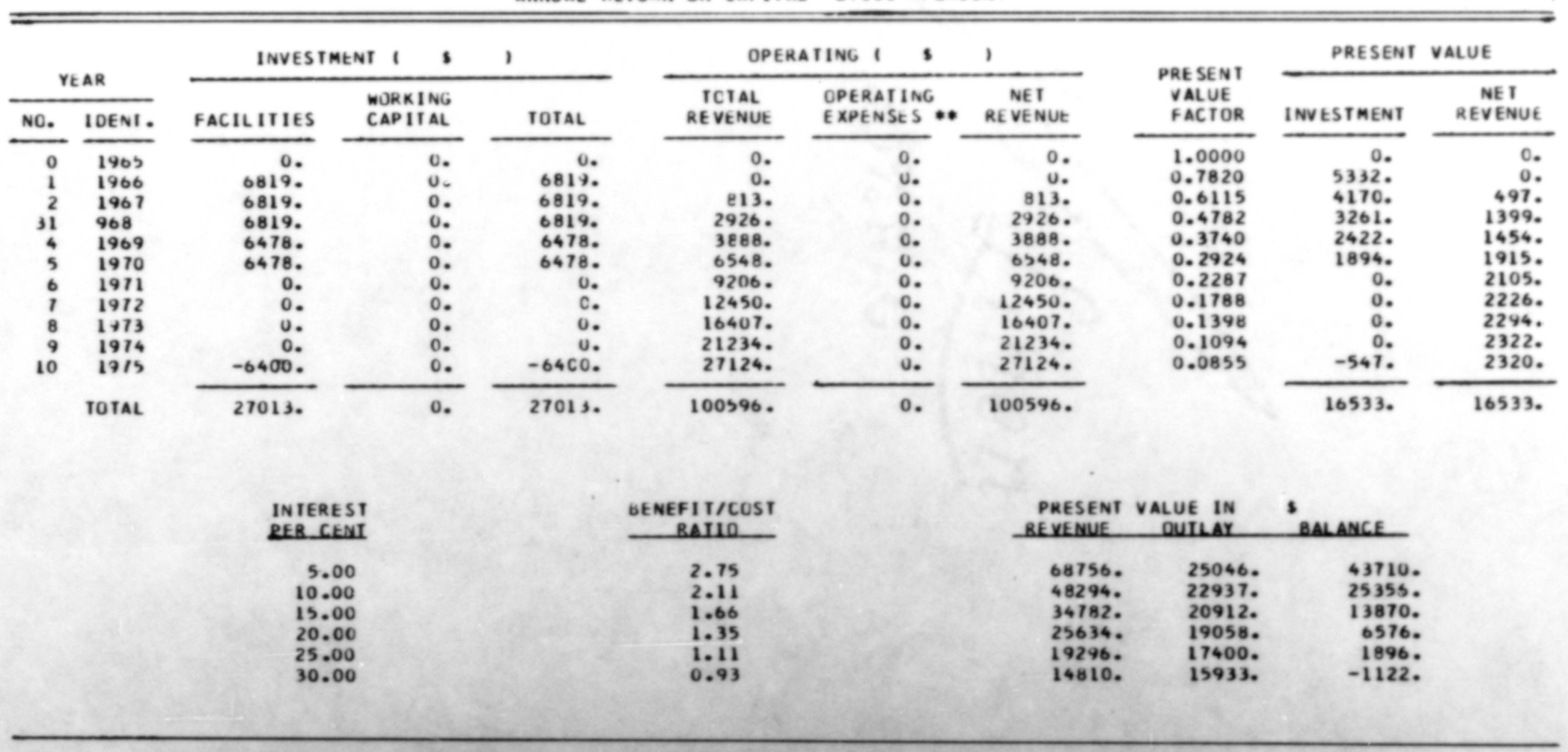

*eexcluding depreciation, interest, and incone tax 
TABLE XXI

INTERNAL RATE OF RETURN ON INVESTMENT AND IMPROVED MANAGEMENT

FOR A REPRESENTATIVE DAIRY FARM

IN THE OZARK DAIRY PROGRAM,

CASE III: NET REVENUE INCREASING AT DECREASING RATE

ANNUAL RETURN ON CAPITAL 23.23 PERCENI

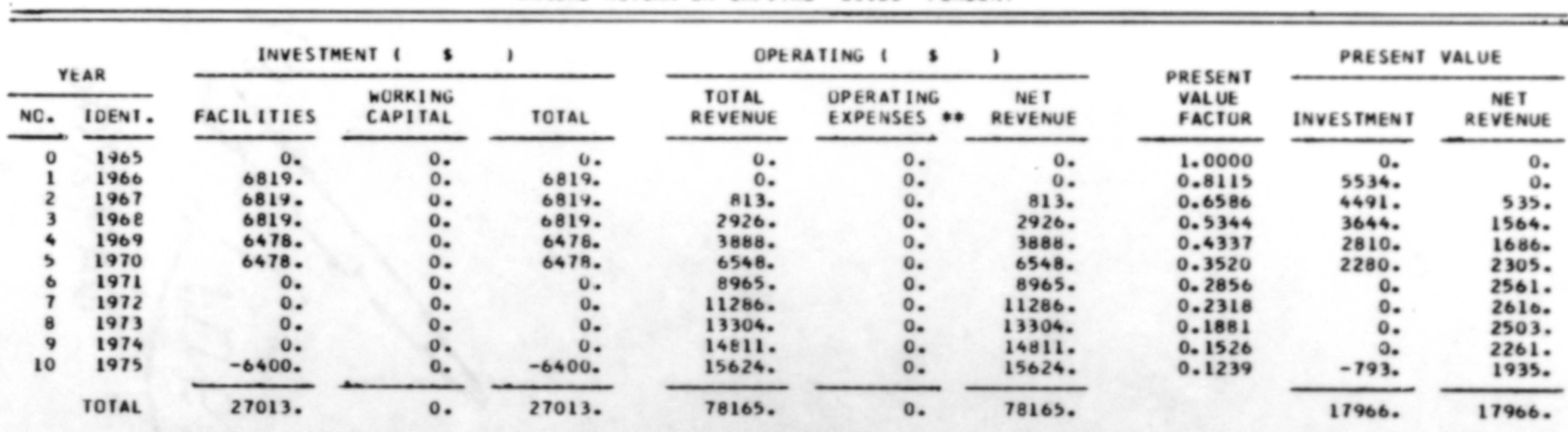

\begin{tabular}{c} 
INIEREST \\
REB_CENI \\
\hline 5.00 \\
10.00 \\
15.00 \\
20.00 \\
25.00 \\
30.00
\end{tabular}

BENEFIT/COST

BAIL

2.17

1.10

1.37

1.12

0.94

0.94
PRESENT VALUE IN

BEYENUE OUILAY BALANGE

54449. 25046. 29403.

38955. 22937.16018.

28557.020912 .075$.

21404.2347.

$\begin{array}{lll}16371 . & 17400 . & -1028 . \\ 12755 . & 15933 . & -3178 .\end{array}$

**excluding depreciation, Interest, and inccme tax 
TABLE XXII

INTERNAL RATE OF RETURN ON INVESTMENT AND IMPROVED MANAGEMENT

FOR A REPRESENTATIVE DAIRY FARM

IN THE OZARK DAIRY PROGRAM;

CASE IV: NET REVENUE INCREASING AT CONSTANT RATE

ANNUAL RETURN UN CAPITAL 25.22 PERCENT

\begin{tabular}{|c|c|c|c|c|c|c|c|c|c|c|c|}
\hline \multicolumn{2}{|c|}{ YEAR } & \multirow[b]{2}{*}{ FACILITIES } & \multirow{2}{*}{\multicolumn{2}{|c|}{ 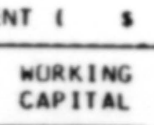 }} & \multirow{2}{*}{1} & \multicolumn{2}{|c|}{ OPERATING I } & \multirow{2}{*}{$\frac{1}{\substack{\text { NET } \\
\text { RE VE NUE }}}$} & \multirow{2}{*}{$\begin{array}{l}\text { PRE SENT } \\
\text { VALUE } \\
\text { FACTOR }\end{array}$} & \multirow{2}{*}{$\begin{array}{l}\text { PRESENT } \\
\text { INV ESTMENT }\end{array}$} & \multirow{2}{*}{$\begin{array}{c}\text { VALUE } \\
\text { NE T } \\
\text { REVENUE }\end{array}$} \\
\hline NO. & IDENT. & & & & & $\begin{array}{c}\text { TCTAL } \\
\text { RE VENUE }\end{array}$ & $\begin{array}{l}\text { UPERATING } \\
\text { EXPENSES *. }\end{array}$ & & & & \\
\hline $\begin{array}{r}0 \\
1 \\
2 \\
3 \\
4 \\
5 \\
6 \\
7 \\
8 \\
9 \\
10\end{array}$ & $\begin{array}{l}1965 \\
1966 \\
1967 \\
1968 \\
1969 \\
1970 \\
1971 \\
1972 \\
1973 \\
1974 \\
1975\end{array}$ & $\begin{array}{r}0 . \\
6819 . \\
6819 . \\
6819 . \\
6478 . \\
6478 . \\
0 . \\
0 . \\
0 . \\
0 . \\
-6400 .\end{array}$ & & $\begin{array}{l}0 . \\
0 . \\
0 . \\
0 . \\
0 . \\
0 . \\
0 . \\
0 . \\
0 . \\
0 . \\
0 .\end{array}$ & $\begin{array}{r}0 . \\
6819 . \\
6819 . \\
6819 . \\
6478 . \\
6478 . \\
0 . \\
0 . \\
0 . \\
0 . \\
-64 c 0 .\end{array}$ & $\begin{array}{r}0 . \\
0 . \\
813 . \\
2926 . \\
3888 . \\
6548 . \\
9208 . \\
11868 . \\
14528 . \\
17188 . \\
19848 .\end{array}$ & $\begin{array}{l}0 . \\
0 . \\
0 . \\
0 . \\
0 . \\
0 . \\
0 . \\
0 . \\
0 . \\
0 . \\
0 .\end{array}$ & $\begin{array}{r}0 . \\
0 . \\
813 . \\
2926 . \\
3888 . \\
6548 . \\
9208 . \\
11868 . \\
14528 . \\
17188 . \\
19848 .\end{array}$ & $\begin{array}{l}1.0000 \\
0.7986 \\
0.6377 \\
0.5093 \\
0.4067 \\
0.3248 \\
0.2594 \\
0.2071 \\
0.1654 \\
0.1321 \\
0.1055\end{array}$ & $\begin{array}{r}0 . \\
5446 . \\
4349 . \\
3473 . \\
2635 . \\
2104 . \\
0 . \\
0 . \\
0 . \\
0 . \\
-675 .\end{array}$ & $\begin{array}{r}0 . \\
0 . \\
518 . \\
1490 . \\
1581 . \\
2127 . \\
2386 . \\
2458 . \\
2403 . \\
2270 . \\
2094 .\end{array}$ \\
\hline & Total & 27013. & & 0. & 27013. & 86815. & 0. & 86815. & & 17331. & 17331. \\
\hline
\end{tabular}

\begin{tabular}{|c|c|c|c|c|}
\hline $\begin{array}{l}\text { INTEREST } \\
\text { PER CENI }\end{array}$ & $\begin{array}{c}\text { BENEF I T/COST } \\
\text { BATL } \\
\end{array}$ & $\begin{array}{l}\text { PRESENT } \\
\text { REYENUE }\end{array}$ & $\begin{array}{r}\text { VALUE IN } \\
\text { OUILAY }\end{array}$ & SBLANGE \\
\hline $\begin{array}{r}5.00 \\
10.00 \\
15.00 \\
20.00 \\
25.00 \\
30.00\end{array}$ & $\begin{array}{l}2.40 \\
1.86 \\
1.48 \\
1.21 \\
1.01 \\
0.85\end{array}$ & $\begin{array}{l}59997 . \\
42599 . \\
31001 . \\
23076 . \\
17535 . \\
13578 .\end{array}$ & $\begin{array}{l}25046 . \\
22937 . \\
20912 . \\
19058 . \\
17400 . \\
15933 .\end{array}$ & $\begin{array}{r}34951 . \\
19661 . \\
10089 . \\
4018 . \\
135 . \\
-2354 .\end{array}$ \\
\hline
\end{tabular}


primary benefits after taking account of expected conditions throughout the economy with and without the enterprise. 39

The tangible benefits included in this analysis were participant's income from gross milk sales of less feed costs. Other tangible benefits not included were (1) salaries of aides and (2) increased asset value of participants. Values for the latter categories would have appeared in both schedules i.e., investment and benefit. However, had they been included in the benefit schedule the internal rate of return would have been greater. Secondary benefits resulting from the component were not measured. Some secondary benefits such as educational spill-over from training programs, employment assistance, and personnel career advancement, are also known to have been realized.

The schedule of net benefits was derived for the first five years of the analysis by use of the following formula,

$$
\begin{aligned}
& \text { (1966) } \mathrm{NB}_{\mathrm{t}}=\left[\mathrm{TR}_{\mathrm{t}}-\mathrm{OB}_{\mathrm{t}}\right]-\left[\mathrm{TR}_{\mathrm{t}-1}-\mathrm{OB}_{\mathrm{t}-1}\right] \\
& (1967) \quad \mathrm{NB}_{\mathrm{t}+1}=\left[\mathrm{TR}_{\mathrm{t}+1}-\mathrm{OB}_{\mathrm{t}+1}\right]-\left[\mathrm{NB}_{\mathrm{t}}\right] \\
& (1970) \quad \mathrm{NB}_{\mathrm{t}+\mathrm{n}}=\left[\mathrm{TR}_{\mathrm{t}+\mathrm{n}}-\mathrm{OB}_{\mathrm{t}+n}\right]-\left[\mathrm{NB}_{\mathrm{t}+\mathrm{n}-1}\right]
\end{aligned}
$$

${ }^{39}$ Proposed Practices for Economic Analysis of River Basin Projects (A Teport prepared by the subcominttee on evaluation standards. Washington, D. C.. May, 1958), p. 8. 
Where:

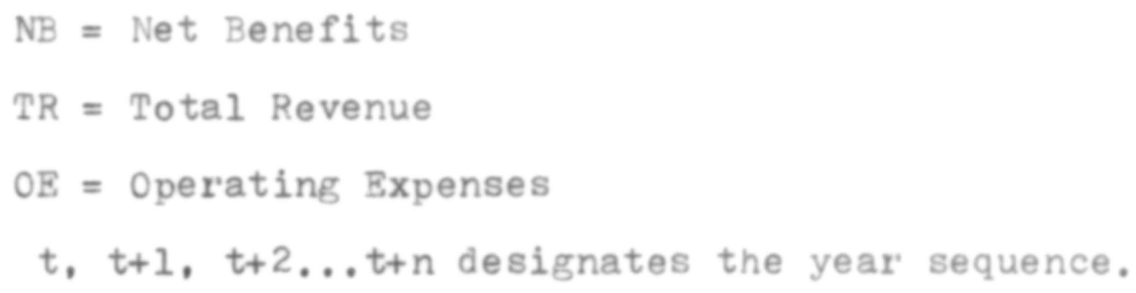

\section{Assumptions Regarding Net Benefits}

Projections regarding the flow of benefits were based upon assumptions regarding the marginal increase in milk sales per farm (on the average) that could be logically attributed to participation in the dairy project. Several possible situations were considered since no projection of the future can be perfectly accurate. A ten year period was used in computing benefits.

1. The "first case" assumed that Net Benefits 40 would reflect "no change" in production or efficiency per farm beyond the fifth year, i.e., NB would be constant for years $t+5 \ldots t+n$. The underlying assumption had to be that there was no further change in investment, average production, prices, nor any other variable which would influence net revenue for years six through 10. An alternative

${ }^{40}$ Net Benefits (NB) for year t+i is defined as total revenue from milk sales in year $t+i$ minus feed costs in year $t+1$ less income over feed costs for the base year t $(1966)$. 
assumption was that if changes in variables should occur, they would have equal and off-setting effects.

2. The second case assumed that NB values for the latter five years would increase at the average rate as during the initial five years for which data were available. The formula used was;

$$
\begin{aligned}
& P R I=\frac{1}{k}=\sum_{t=1}^{K} \frac{{ }^{N B} t_{t+1}-N_{t}}{N_{t}}+\frac{{ }^{N B} t_{t+2}-{ }^{N B} t+1}{N B_{t+1}}+\cdots \\
& \cdots \frac{{ }^{N B_{t+k-1}}-N_{t+k-2}}{N_{t+k-2}}
\end{aligned}
$$

Where :

$$
\begin{aligned}
\text { PRI = } & \text { Projected Rate of Increase in Income Over } \\
& \text { Feed Costs. } \\
\text { NB = } & \text { Income Over Feed Costs Per Herd. }
\end{aligned}
$$
and; $t=1,2 \ldots k$ designates the year sequence. The average rate of change (PRI) over the period 1966-1970 was 20 percent per annum. Assuming such a change requires that $\mathrm{NB}$ increased at an "increasing rate." Theoretically, this would infer that the effect felt from the investment would have a "snowballing" effect over the ten years.

3. The third case assumed that net benefits increased at a diminishing rate. The rates of change for 
the respective years were:

(a) Year 6 net benefits were 20 percent greater than year 5 .

(b) Year 7 net benefits were 16 percent greater than year 6 .

(c) Year 8 net benefits were 12 percent greater than year ?.

(d) Year 9 net benefits were 8 percent greater than year 8 .

(e) Year 10 net benefits were 4 percent greater than year 9 .

4. The fourth case assumed the net benefits increased at a constant rate for each year beyond year five. The rate of change achieved between years three and four was projected as a linear rate through year 10.

\section{Case I Results}

Table XIX summarizes the investment and projected flow of benefits (NB) over the period projected. The internal rate of return on capital invested was 12 percent. The 12 percent IRR may be conservative because the analysis was based on the assumption of no change in production, prices, milk quality, nor feed efficiency over the latter half of the ten year period. 
When the investment and net benefit schedules were discounted at rates (5 and 10) lower than the IRR; the benefit-cost ratios were greater than 1.0, i.e., (1.35 and 1.09). A discount rate of 12 percent (the same as IRR) would yield a corresponding $B / C$ ratio of 1.0 .

\section{Case II Results}

As shown in Table $X X$ the internal rate of return was 28 percent. The increased IRR in case II was attributed to the assumption that net benefits would increase at a per annum rate of 20 percent for the entire ten year period.

Theoretically, the 20 percent yearly increase suggests an increasing marginal productivity of capital. The assumption places the farmers at some point in stage one for capital.

The benefit-cost ratios for all discounting rates ranged between 0.93 and 2.75. For all discount rates greater than 28 (IRR), the $B / C$ ratio was less than 1.0 . The often used five percent discount rate had a $B / C$ ratio of 2.75 .

Case III Results

The projected trend for NB was that of increasing at a "diminishing rate" over the latter five years. Assuming NB to have been $\$ 813$ in 1967 and $\$ 15,624$ by 
1975, the IRR on capital invested was calculated to be 23 percent. These data are contained in Table XXI. The assumption specified that the effect of the initial stream of investment, which was terminated in year five, would produce successively smaller increases in production over the latter five years (1971-1975). Hence, a "tapering-off" investment impact would be realized.

\section{Case IV Results}

The results of case IV are presented in Table XXII. Based on assumed constant incremental increases in net revenue over the latter five years the IRR value was 25. All B/C ratios, were greater than one, with the exception of the $B / C$ ratio discounted at the discount rate of 30.0. A benefit-cost ratio of 2.4 corresponded to a discount rate of five percent.

\section{Implications of IRR Analysis}

Cases I. through IV, based on varying assumptions regarding the flows of net revenue over the latter five years of the analysis period, yielded IRR values of 12, 28, 23 , and 25 respectively. The IRR values obtained reveal substantial returns to capital investment. Though the component project was terminated in 1970, Cases I through IV attempted to assess the ongoing 
and future impacts of investment, and incidence of component participation.

These results have important implications, considering the very different assumptions underlying the cases. Except for the very conservative case, the IRR was 23 percent and more. If half the IRR could be attributed to the dairy component, the returns on public investment may be great enough to make other similar dairy projects economically feasible. 
SUMMARY, CONCLUSIONS AND RECOMIENDATIONS

\section{SUMMARY}

It was the purpose of this study to analyze the Ozark Dairy Management Component, its purpose and objectives and to determine by comparison to documented performance, the degree of progression toward objective accomplishment. The analysis was hindered by incomplete data. Moreover, the findings are limited to a selectively delineated segment of project participants; i.e., participants who had also participated in the DHIA record keeping program.

Findings revealed that income over feed cost per herd and per cow, for herds in the analysis, increased over the observed period. Median income over feed cost per herd and per cow, stood at $\$ 8,679$ dollars and $\$ 270$ respectively, during the third year of component participation. Income over feed costs, for the most part, doubled in less than three years. While such might have been considered ordinary for larger and more efficient producers, it appeared to have been a significant accomplishment for low income dairy farmers.

Though it was not the intention to increase per 
herd cow number, but to enhance adjustment of herd size to operator investment, time, and labor availability; most herds realized increased size without loss in production per cow or value of product. To follow herd change over a three year period, the thirty herds were divided into three herd size categories. They were: (1) 25 or less cows, (2) 26 to 35 cows, and (3) 36 or more cows. In the year of project inception, 40 percent, 33 percent, and 27 percent of the thirty sample herds were ranked in the respective categories. By the third year of component participation the proportions had changed to 17 percent; 42 percent, and 43 percent in the three categories. Thus, in three years there was a general growth in herd size. Improving production per cow suggested a concomitant increase in livestock quality and/or management practices. Through the aid of owner-sampler testing procedures, farmers were able to achieve selective culling whereby low producers were replaced by better quality stock.

Median feed costs per cow per day were consistent with economic theory on economics of size. Larger herds generally had lower feed costs per day and per unit of production. 


\section{Investment}

Most of the farmers borrowed capital. Those sources of credit patronized by the farmers were;

(1) Production Credit Association, (2) Farmers Home Administration, (3) Banks, (4) Local Merchants, (5) Loan Association, and (6) Family members or other relatives. While all the above sources were drawn upon for investment capital; banks, P.C.A., and F.H.A. were reportedly patronized most heavily. The magnitude of investment varied by the length of time dairymen had been associated with the component. Farmers who had been with the program the longest borrowed less per man. Average annual investment for the period 1966-1970 by length of association with the program was as follows: (1) "One-to-two years participation" $\$ 6,766$ dollars, (2) "Two-three-years participation" $\$ 6,931$, (3) "Four-to-five years participation" $\$ 4,716$.

\section{Use of Investment}

The capital secured from sources identified earlier were invested in four asset types. They were, acquisition and/or improvement in milking facilities and equipment, (2) acquisition of dairy animals for herd expansion and/or replacement of lower quality animals, (3) acquisition and/or improvement of machinery and, (4) purchase of land. The proportion of capital used to 
purchase land was high relative to capital use in other types of investment.

Dairymen who had been associated with the component the longest ( 5 years) invested most heavily in herd expansion. Herd expansion was the asset type expected to give the greatest return on investment.

Repayment terms of loans suggested that farmers were able to borrow both short and long term capital. Almost 45 percent of the total loans made between 1966 and 1970 had repayment terms of three years and longer. The dairymen relied very little on assistance from personnel with the dairy project when obtaining a loan.

\section{Investment Feasibility}

The Internal Rate of Return was chosen as a means of measuring economic returns because; (1) it required a minimum of assumptions and judgements, (2) it did not require the specification of a discount rate, and (3) it reflected percent return.

The two sets of data required for calculating IRR were a schedule of total capital investment, and a schedule of net revenue over the specified period. The period of the analysis covered ten years (1966-1975). The flow of investment was assumed to have been injected in amounts of $\$ 6,819$ per annum over the period 1966-1968, 
and $\$ 6,478$ per annum over years 1969 and 1970. The flow of net revenue for the years 1966, 1967--1970, was; $\$ 0.00, \$ 813, \$ 2,926, \$ 3,888$; and $\$ 6,548$. All investment was assumed to have been made in the initial five years. The flow of net benefits for the 1966-1975 period was projected for four sets of assumptions. The first case examined assumed no improvement in productivity once a dairyman terminated association with the dairy component. A 12 percent IRR on private investment was computed for this rather conservative assumption.

The most optimistic situation examined assumed net benefits increased at an increasing rate of 20 percent during 1971-1975. The increase was assumed to accrue from production efficiency and herd expansion. The corresponding IRR was 28 percent.

The third case assumption was that net benefits would "increase at a diminishing" rate over the latter five years of analysis. The corresponding IRR was 23 percent. The fourth case assumption was that net benefits would "increase at a constant" rate over the latter five years of analysis. The corresponding IRR was 25 percent. Bven though the component project was terminated in 1970, the four cases and conditions allowed for projecting possible future impact beyond termination. The subsequent 
results suggested that project associated investment would yield substantial rates of return. Therefore it was concluded, provided the assumptions are logical, that the investment made was practically feasible.

\section{Participant Perception of the Component}

For the most part, participants felt that subsequent to participation in the component their abilities to do a good job at dairying had improved. However, sixteen percent indicated that their abilities had not improved, and another thirteen percent did not care to comment. of notable interest, was that the farmers indicating no improvement were among the group of shorter participation. Generally those farmers' records showed superior performance in management, while other data suggest that they were heavier uses of investment and were concomitantly extended the greater proportions of long term financing. The majority of the farmers included in the sample indicated that the assistance received from leader aides was satisfactory to extremely satisfactory. This suggests support for the theory that "farmers communicate better with their peers."

Participation in meetings and tours was minimal on the part of many participants. Reflected in the low level of participation, was the ever present problem of 
motivating farmers of such caliber to join in externally directed processes for farmer and community betterment.

\section{CONCLUSIONS}

Based on the analysis which this investigation provided and with respect to the findings, the following conclusions were drawn:

1. It appears that the Ozark Dairy Management Component, over the first three years of operation, realized substantial progress in the accomplishment of some of its objectives. (All objectives were not investigated).

2. Income over feed costs for the group improved at an average rate greater than the five to ten percent that might be normally expected.

3. Dairymen who participated the shortest length of time were initially closer to minimum income guidelines as set by $\mathrm{OBO}$, and were relatively better managers.

4. That the investments made in conjunction with the component yielded substantial return. (All benefits were not evaluated.)

5. That the dairy farmers were receptive to the component program, though many did not participate actively in meetings and tours. 
6. That the use of peers (other low income dairy farmers) as project personnel was a worthwhile practice and perhaps enhanced communication.

\section{RECOMMENDATIONS}

Based solely upon the experiences gained and observation made during the course of this study the writer offers the following recommendations:

1. That sound and realistic bases for project proposition and implementation be employed so that projects selected and implemented will contribute substantially to the mitigation of economic inequity rather than enhance political ploy.

2. That development projects be subject to continuous evaluation, and that the evaluators should be highly trained individuals who are not internally involved (internal survival often impedes program progress).

3. That comprehensive evaluation of development projects should be executed so as to allow observation of the sometimes "over-looked benefits" and "over-looked" costs.

4. That some pre-planned evaluation guidelines be established which would provide for continuous 
and uniform collection and storage of evaluative type data for present and future uses.

5. That the findings of this study be further studied and evaluated for use. 


\section{BIBLIOGRAPHY}




\section{BIBLIOGRAPHY}

Bender, L. D., Rhodes, V. J. "Spotlight on the Ozarks," Department of Agricuitural Economics University of Missouri-Columbia, Missouri, July-August, 1966.

Bender, Lloyd D. et al. "Congruence Between Aspirations and Capabilities of Youth In A Low Income Area." (Reprinted from Rural Sociology, Volume 52, No. 3, September, 1967), pp. 278-289.

Bender, Lloyd D. and Jordan, Max F. "An Economic Survey of the Ozark Region." (Agricultural Economic Report No. 97) Bconomic Research Service--United States Department of Agriculture July 1966.

Bertrand, A. L. Bryan, C. H. "Propensity to Change Among Rural Poor in the Mississippi Delta;" A Study of the Roots of Social Mobility. (Agricultural Economics Report No. 185). B.R.S. U.S.D.A. In cooperation with the Louisiana State University Bxperiment Station, June, 1970.

Bottom, Carrol J. "Community Development Operation." The American Journal of Agricultural Economics, Volume 50, No. 5, December, 1969, p. $\overline{1239 .}$

Braschler, C. H. and Hagerman, D. L. "An Analysis of the Impact of Industrialization on a Small Town: A Case Study of Ava, Missouri." Research Bulletin No. 910, University of Missouri Agricultural Bxperiment Station, Columbia, Missouri, July, 1966.

Crecink, John C. and Steptoe, Roosevelt. "Human Resources in the Mississippi Delta... With Emphasis on the Poor." (Agricultural Bconomic Report No. 170) United States Department of Agriculture--Bconomic Research Service. January, 1970.

Eckstein, Otto. Water Resource Development. Bconomics of Project Evaluation, Harvard University Press, Cambridge, Massachusetts, 1968.

Fligele, Frederick C. "The Low-Income Parmer in a Changing Society." The Pennsylvania State University College of Agriculture Agricultural Bxperiment Station University Park, Pennsylvania, pp. 37 Bulletin 731 , March 1966. 
Griener, Frank. "The Economic Feasibility of a Feeder Pig Component Project." A Masters Degree Paper, College of Agriculture, University of MissouriColumbia, Missouri, 1970.

Holmes, 0. W. "The Impact of Public Spending in a Low Income Rural Area, A Case Study of Fort Leonard Wood, Missouri." (Agricultural Economics Report No. 135), Washington, D. C., June, 1968, p. 24.

Hoover, Herbert. "Rural Industrialization in West Virginia." A Case Study of a Plant in Braxton County, West Virginia. (Economic Research Service--United States Department of Agriculture, Washington, D. C.

Jones, E. Walton. "Nature and Extent of Rural Poverty," Papers on Rural Poverty. Agricultural Policy Institute, School of Agriculture and Life Science, North Carolina State University, December 1968.

Keyserling, Leon H. Progress or Poverty. Conference on Economic Progress, 1001 Connecuit Avenue, N. W. Washington, D. C. December, 1964.

Kuehn, John Allen. "Highway Impacts on Ozarks Incomes and Employment." Unpublished Ph.D. Dissertation, University of Missouri, Columbia, 1970.

Levitan, Sar A. The Great Society's Poor Law--A New Approach to Poverty. (The John Hopkins Press, Baltimore, Maryland, 1969, p. 3).

office of Bconomic Opportunity Information Center, "Community Profiles," (An indepth look at Missouri County Bconomic base and resources) 1966.

Ornati, 0scar. Poverty Amid Affluence. New York: The Twentieth Century Fund, 1966.

Phillips, H. S. Guide for Development, Institution Building and Reform. (Frederick A. Praeger Publishers, New York, Washington, London, 1969).

Phillips, Richard. "Internal Rate of Return," Unpublished paper on Project Feasibility Analysis, Agricultural Research Service, Manhattan, Kansas, 1970. 
Ratchford, Brice C. "Role of State and Land-Grant University Extension Services in Eliminating Rural Poverty." University of Missouri Extension Division Publication, November, 1967, Columbia, Missouri.

Smith, Stephen C. and Castle, B. N. Economics and Public Policy in Water Resource Development, Ames; lowa state University Press, 1965.

Steward, Donald D. "Impact of Economic Opportunity Loans on Rural Residents." South Carolina, The Ozarks, Mississippi Delta. Bconomic Development Division-E.R.S. (Report No. 151)

Stewart, Clyde E. "Secondary Benefit Evaluation in Federal Reclamation Programs." Secondary Impacts of Public Investment In Natural Resources. (Publication No. 117 V.S.D.A.--E.R.S. September 1968).

The President's National Advisory Commission on Rural Poverty. The People Left Behind. Issued September 1967, Washington, D. C.

The Proposors of the "Ozark Dairy Management Component." The original proposal submitted April, 1966, Ozark Area Community Action Cooperation.

Tiebout, Charles M. "The Community Economic Base Study" (Supplementary paper No, 16, published by The Committee for Economic Development, December, 1962).

United States Bureau of Census, United States Census of Agriculture (Missouri Volume 1 part 17 ) 1964 .

West, Jerry G. "Evaluation of the People Left Behind." Papers on Rural Poverty. Agricultural Policy Institute, School of Agriculture and Life Science, North Carolina State University, December 1968. 
APPENDIX A

COMMUNICATION AND CORRESPONDENCE LETTERS 
March 5, 1971

Dear Sir:

You have been selected as one of a group of dairymen to provide opinions on the Ozark Dairy Program. You were selected because of the management potential you displayed while participating in the Dairy Program.

I am a graduate student in the College of Agriculture. I am working on a project to evaluate the effectiveness of programs that use leader aides. To complete the project, I need some information from farmers with whom leader aides have worked. In that regard, you will receive a brief information survey in the near future. Please fill out the survey and return it promptly.

All replies you give will be confidential. We will not need your name. We are interested in the aggregate results of the sample. No information on individual responses will be divulged.

Thanking you in advance for your cooperation, I am Sincerely yours,

Handy Williamson, Jr. Graduate Student 
March 19, 1971

Dear Sir:

A few days ago you received a letter of notification regarding your selection as one of a group of dairymen to provide opinions on the 0zark dairy program. Also mentioned, in that letter was the check list which you will find enclosed.

May we ask your cooperation by completing the check list and returning it to us immediately. To guarantee accurateness, please read each of the eight items carefully and respond by placing a check mark or figure on the lines where required. If there should be a question, to which you do not know the answer, write "I don't know" near the question.

We are aware of the value of your time and have accordingly made the check list brief. Again, may we thank you in advance for your cooperation.

Sincerely yours,

Handy Williamson, Jr. Graduate Student 


\section{APPENDIX B}

QUEST IONNAIRE 


\section{UNIVERSITY OF MISSOURI - COLUMBIA \\ COLLEGE OF AGRICULTURE \\ (Confidential Information)}

Name: (optional) Herd Code:

1. My age, to the nearest birthday, is:

2. My wife's age to her nearest birthday is:

3. The number of children and dependents living in my home
A. 0
B. $1-3$
c. 4-6
D. more than six

4. The number of years I have completed in school are (check appropriate category)
A. none
B. $1-4$ years
C. 5-7 years
D. 8 years

$\mathrm{B}$. 9-11 years

F. 12 years

G. 13-15 years

H. 16 years and over

5. I first began...

A. farming on my own in 19

B. dairy farming on my own in 19

6. Have you been dairying every year since you first started?
A. yes
B. no
C. If no, how many years have you been in dairying? years.


7. In the years 1966 and 1970 I; (check appropriate blank) A. Owned:

$0-20$ acres

21-50 acres

51-100 acres

101 or more acres

B. Rented from another party

$0-20$ acres

21-50 acres

51-100 acres

101 or more acres

C. Rented out to another party

$0-20$ acres

21-50 acres

51-100 acres

101 or more acres

8. The acreage (owned plus rented in) operated in 1966 and 1970 (check appropriate blank)

A. Tillable:

$$
\begin{aligned}
& 0-20 \\
& 21-50 \\
& 51-100 \\
& 101 \text { or more acres }
\end{aligned}
$$


B. In grain:

$$
0-20
$$

$21-50$

$51-100$

101 or more

C. Open pasture:

$$
0-20
$$

21-50

$51-100$

101 or more

D. In woodland, roads, farmstead

$$
0-20
$$$$
\text { 21-50 }
$$$$
51-100
$$

101 or more
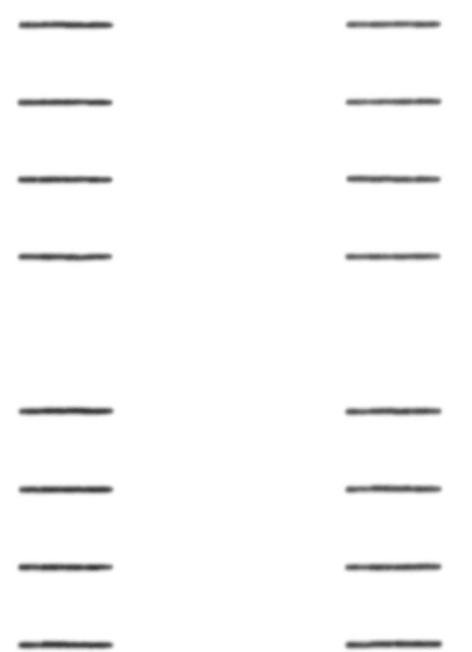

9. In 1966 and 1970, the type milking facility I used was (check appropriate facility owned for each year)
A. Stanchion
no of stanchions
$\underline{1966}$
$\underline{1970}$
parlor
pipeline
bucket
C. Walk through
D. Herringbone

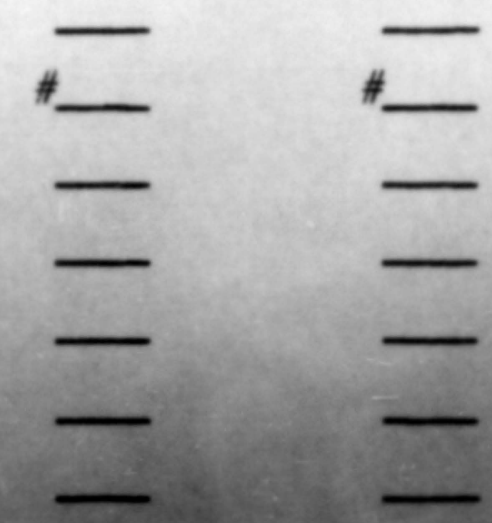


10. In 1966 and 1970, the loafing facility I used was (check appropriate facility and year)

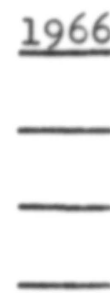

11. In 1966 and 1970, my method and frequency of manure and waste disposal was (check appropriate method under $A$, and frequency under $B$ )

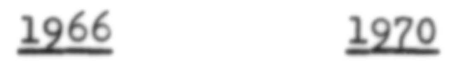

A. Type disposal unit

1) Manure spreader

2) Flail type spreader

3) Liquid manure wagon

4) Tractor \& Blade

5) Tractor with front end loader

6) Manure chute

7) Liquid manure pump

8) Lagoon for wastes from parlor

B. Frequency of Manure Clean-up
1) Daily
2) Weekly
3) Monthly
4) Other (11st) 
12. Of the concentrates fed in 1966 and 1970, I. . (check appropriate answer for each year)
$\underline{1966}$
$\underline{1970}$
A. grew all
B. grew part
C. percent you grew
D. purchase all

13. Of the forage fed in 1966 and 1970, I . . . (check appropriate answer for each year)
$\underline{1966}$
$\underline{1970}$
A.
grew all
B. grew part
c. percent you grew
D. purchase all

14. Of the feed fed in 1966 and 1970, I . . . (check appropriate answer for each year)

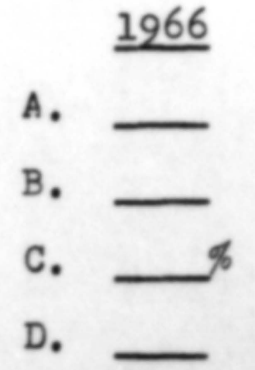

$\underline{1970}$

Over the most recent five years, (since April, 1966) approximately how much have you invested in...

A. Milking facilities and equipment?

B. Herd expansion? Number of head

c. Machinery?

D. Land? 
16. Over the most recent five years, (since April, 1966) I secured credit from . . . (check appropriate source or sources)
A. P.C.A.
B. F.H.A.
C. Bank
D. Local Merchant
E. Loan Association
F. Other (1ist)

17. Of the loans secured over the past five years, how many had to be repaid within...
A. 1 to 12 months
B. 13 to 16 months
C. 17 to 36 months
D. 36 months or more

18. Did someone with the Ozark Dairy Component help you secure the loan(s)?

yes

no

if yes, was his help...

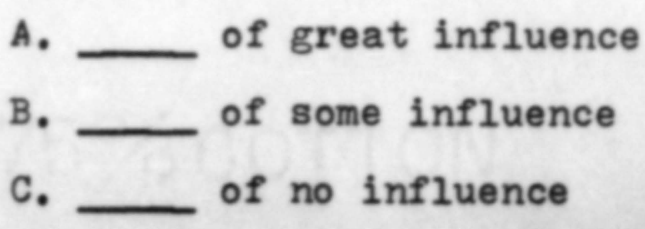

BMPLOYMENT DATA

19. If you also work off-farm, how many hours per week (day) is spent at work? 


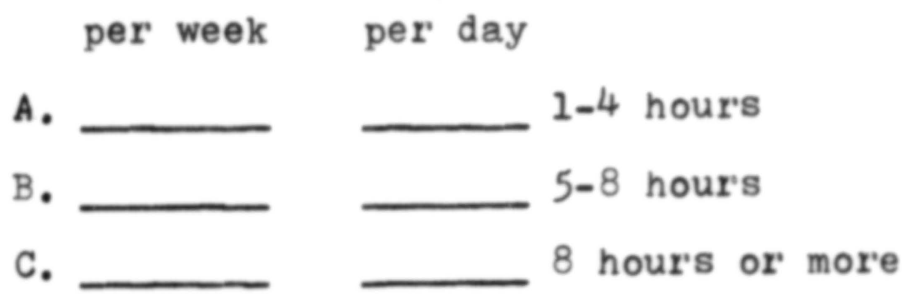

20. How many weeks per year do you work, at your off-farm job per year?
A. 1-9 weeks
B. 10-24 weeks
C. $30-49$ weeks
D. 50 or more weeks

21. If you work at an off-farm job only a few weeks per year, specify the season...
A. spring
B. summer
C. fall
D. winter
B. other

22. Approximately, how many miles (one way) do you drive to your off-farm job?
A. 0-9 miles
B. 10-19 miles
C. 20 miles or more

23. Amount received per hour at off-farm job...
A. less than $\$ 1.00$
B. 1.00 to 1.50
C. 1.51 to 2.00
D. 2.01 to 2.50
B. over 2.50 
24. If you are not presently engaged in off-farm work, what wage would induce you to take an off-farm job?
A. about $\$ 2.50$
B.
$\$ 1.50$ to $\$ 2.50$
C. below $\$ 1.50$

\section{ATTITUDINAL DATA}

25. In my opinion, the assistance I received from the dairy aide with the Ozark Dairy Management Component was;
A. completely satisfactory
B. satisfactory
C. unsatisfactory

26. Resultant from the Ozark Dairy Management Component, I feel that my ability to do a good job at dairying:

A. has improved a lot

B. has improved some

c. has not improved

27. Of the meetings and tours sponsored by the Ozark Dairy Management Component (during the time period in which you participated) did you attend:
A. all of them
B. some of them
C. none of them 
28. Rank the following potential limitations to the expansion of your dairy operation (using the numbers $1,2 . .7$, list the most potential limiting factor

1 and the next 2, etc.) please rank at least three.
A. age
B. management ability
C. labor cost
D. labor availability
B. credit availability
F. low monetary returns
G. other (1ist)

29. I plan, within the next five years to ... A. expand the size of my operation B. retain my present size of operation

c. decrease the size of my operation

D. retire from dairying

30. If you plan to expand, which of the following will apply (may be more than one): increase dairy herd increase beef herd upgrade milking facilities improve waste handling methods add swine enterprise 
increase size of present swine enterprise increase acres of forage crops add irrigation other (specify),

Thank you 
University Libraries

University of Missouri

Digitization Information for Theses and Dissertations project. Scanned from microfilm; no subsequent editing done.

Local identifier

Source information

Identifier

Format

Content type

Notes

Capture information

Date captured

Scanner manufacturer/model ScanPro 3000 /e-ImageData

Scanning software

Optical resolution

Compression

Color settings

File types

Notes

Derivatives - Access copy

Editing software

Resolution

Color

File types

Notes
Williamson1971

Microfilm reel\# T210-215

Microfilm

Text

2018

PowerScan $3000(\mathrm{TM})$ v5.341

$600 \mathrm{dpi}$

LZW

bitonal

tiff

Scanned from microfilm; no editing done.

Photoshop

600 dpi

grayscale

pdf

Converted from tiff to pdf using Adobe Acrobat Pro DC. 